Research Paper

\title{
Safety and Efficacy of Suicide Gene Therapy with Adenosine Deaminase 5-Fluorocytosine Silmutaneously in in Vitro Cultures of Melanoma and Retinal Cell Lines
}

\author{
Antonios Sakkas ${ }^{1}$, Paul Zarogoulidis ${ }^{1 凶}$, Kalliopi Domvri ${ }^{1}$, Wolfgang Hohenforst-Schmidt², Dimitris \\ Bougiouklis $^{3}$, Stylianos Kakolyris ${ }^{4}$, Thomas Zarampoukas ${ }^{1}$, Ioannis Kioumis ${ }^{1}$, Georgia Pitsiou1 ${ }^{1}$, Haidong \\ Huang ${ }^{5}$ Qiang Li ${ }^{5}$, Soultana Meditskou ${ }^{6}$, Theodora Tsiouda7, Nikolaos Pezirkianidis ${ }^{8}$, Konstantinos Za- \\ rogoulidis ${ }^{1}$ \\ 1. Pulmonary Department-Oncology Unit, “'G. Papanikolaou“ 'General Hospital, Aristotle University of Thessaloniki, Thessaloniki, Greece \\ 2. II Medical Department, “'Coburg” Regional Clinic, Coburg, Germany. \\ 3. Gene and Cell Therapy Center, Hematology-BMT Unit, “'G. Papanikolaou“ Hospital, Thessaloniki, Greece. \\ 4. Oncology Department, University General Hospital of Alexandroupolis, Alexandroupolis, Greece. \\ 5. Department of Respiratory Diseases, Changhai Hospital/First Affiliated Hospital of the Second Military Medical University, Shanghai, \\ People's Republic of China. \\ 6. Laboratory of Histology, Embryology and Anthropology, Medical School, Aristotle University of Thessaloniki, Thessaloniki, Greece \\ 7. Internal Medicine Department, “Theiageneio" Anticancer Hospital, Thessaloniki, Greece. \\ 8. Surgery Department, Private Cabinet, Serres, Greece.
}

$\triangle$ Corresponding author: Paul Zarogoulidis, Pulmonary Department-Oncology Unit, “G. Papanikolaou“ General Hospital, Aristotle University of Thessaloniki, Thessaloniki, Greece. Tel: +306977271974, Fax: +302310992433, e-mail: pzarog@hotmail.com.

(c) Ivyspring International Publisher. This is an open-access article distributed under the terms of the Creative Commons License (http://creativecommons.org/ licenses/by-nc-nd/3.0/). Reproduction is permitted for personal, noncommercial use, provided that the article is in whole, unmodified, and properly cited.

Received: 2014.03.18; Accepted: 2014.03.23; Published: 2014.04.17

\begin{abstract}
Local treatment as a treatment modality is gaining increased general acceptance over time. Novel drugs and methodologies of local administration are being investigated in an effort to achieve disease local control. Suicide gene therapy is a method that has been investigated as a local treatment with simultaneously distant disease control. In our current experiment we purchased HTB-70 (melanoma cell line, derived from metastatic axillary node) and CRL-2302 (human retinal epithelium) were from ATCC LGC Standards and Ancotil ${ }^{\circledR}, 2.5 \mathrm{~g} / 250 \mathrm{ml}$ ( I g/00ml) (5-Flucytosine) MEDA; Pharmaceuticals Ltd. UK. Adenosine Cytosine Deaminase (Ad.CD) was also used in order to convert the pro-drug 5-Flucytosine to the active 5-Fluoracil. Three different concentrations of 5-Flucytosine $(5-\mathrm{FC})$ were administered $(0.2 \mathrm{ml}, 0.8 \mathrm{ml}$ and $1.2 \mathrm{ml})$. At indicated time-points $(4 \mathrm{~h}, 8 \mathrm{~h}$ and $24 \mathrm{~h}$ ) cell viability and apoptosis were measured. Our concept was to investigate whether suicide gene therapy with Ad. CD-5-FC could be used with safety and efficiency as a future local treatment for melanoma located in the eye cavity. Indeed, our results indicated that in every 5-FC administration had mild cytotoxicity for the retinal cells, while increased apoptosis was observed for the melanoma cell line.
\end{abstract}

Key words: suicide gene therapy, 5-fluorocytosine, melanoma, retinal.

\section{Introduction}

Melanoma is a malignant tumor of melanocytes. ${ }^{1}$ Melanocytes produce the dark pigment, melanin, which is responsible for the color of skin. These cells can be found in skin, but also in other parts of the body, including the bowel and the eye. Uveal melanoma is also an entity that has been reported.2,3 Melanoma can originate in any part of the body that contains melanocytes. Melanoma is less common than 
other skin cancers, however, it is much more aggressive if it is not treated early. ${ }^{1}$ It causes the majority $(75 \%)$ of deaths related to skin cancer. The treatment of choice if it is discovered early is surgical removal of the tumor. ${ }^{4}$ Surgical treatment is successful while it is still small and thin, and if it is completely removed, then the chance of cure is high. The likelihood of relapse or spreading depends on how deeply it has gone into the layers of the skin. For melanoma that relapses or spreads, additional treatments include chemo- and immunotherapy, or radiation therapy. ${ }^{5-8}$ Chemotherapy and radiotherapy have adverse effects and in several situations the patients' treatment has to be postponed. ${ }^{9}$ Moreover, severe bone marrow suppression in many cases requires hospitalization with additional costs for the national health system. 10,11 Novel routes of drug administration are being investigated in an effort to reduce the adverse effects in many types of cancer with different strategies, with the main concept being the local treatment. ${ }^{12-22}$ Additional investigation of cancer pathways revealed underlying mechanisms that could be utilized to block chemotherapy resistance and sensitize tumors to chemotherapy and radiotherapy. ${ }^{23}$ A major breakthrough has been achieved with so called: "suicide gene therapy" modality. The introduction of a therapeutic gene encoding, enzyme capable of transforming a nontoxic pro-drug into a cell toxin enhances the cytotoxic effect for cancer cells and protects the healthy cells. ${ }^{15-17}$ Suicide gene therapy, utilizing the cytosine deaminase/5-fluorocytosine (CD/5-FC) system, is an efficient methodology for targeted therapy in cancer research with favorable results in previously published studies. ${ }^{24-28}$ In specific the cytosine deaminase (CD) enzyme converts the anti-fungal agent 5-Fluorocytosine (5-FC) into its antimetabolite 5-Fluoracile (5-FU), thereby killing tumor cells. Most suicide genes under investigation mediate sensitivity by encoding viral or bacterial enzymes that convert inactive forms of a drug, into toxic metabolites capable of inhibiting nucleic acid synthesis. ${ }^{29,30}$ The second suicide gene therapy methodology that has been extensively investigated is the herpes simplex virus thymidine kinase gene (HSV-tk), which converts ganciclovir (GCV) to ganciclovir monophosphate and inconsequence inside the cancer cell the enzymes covert it to ganciclovir triphosphate .

The bystander effect, through which the Ad.CD system applies, has to do with the fact that a pro-drug is converted into an antineoplastic agent in only a percentage of the target cells expressing the drug activating enzyme. These cells are killed as a result of this expression, thus releasing the newly formed anticancer agent to the tumor microenvironment killing also adjacent cells. ${ }^{29-38}$ The suicide gene therapy has been investigated in several cancer types; a) colon $16,39,40$, b) lung 41,42 , c) liver $17,43,44$, d) medulloblastomas 45 , e) spinal cord tumors ${ }^{46}$, f) neuroendocrine ${ }^{47}, \mathrm{~g}$ ) prostate $48, \mathrm{~h}$ ) breast 49,50, i) bladder $51, \mathrm{j}$ ) head and neck $52, \mathrm{k}$ ) brain 53,1 ) gliomas $54-56, \mathrm{~m}$ ) sarcomas 57 and n) melanoma (HSV-tk- GCV) ${ }^{58}$. The suicide gene modality has been also investigated as; a) anti-vascular endothelial treatment 59,60, b) interleukin-12 (IL-12) 61 and c) immune stimulation with interleukin- 7 (IL-7). ${ }^{62}$ (Table 1.) Moreover, suicide gene therapy has been proven to be efficient in chemotherapy resistant cancer cell lines ${ }^{63}$ and to enhance radiotherapy treatment modality. ${ }^{64}$ Additional control of micrometastasis has also been observed in suicide gene therapy studies. ${ }^{65}$ In the current in vitro study we investigated the safety and efficiency of ad.CD-5-FC in melanoma and uveal cell lines and proposed a future method of local administration for primary or metastatic uveal melanoma treatment methodology.

Table I. Suicide Gene Therapy Studies.

\begin{tabular}{|c|c|c|c|c|c|}
\hline Author & Cells lines & Design & Result & Transport & Ref \\
\hline $\begin{array}{l}\text { Michaelsen } \\
\text { S. R. } \\
\text { et al. }\end{array}$ & $\begin{array}{l}\text { GLC-14, GLC-16, } \\
\text { GLC-19, NCI-H69, } \\
\text { H69-VP, H69-CPR, } \\
\text { H69-DAU, H69-BCNU }\end{array}$ & $\begin{array}{l}\text { In Vitro } \\
\text { In Vivo }\end{array}$ & $\begin{array}{l}\text { Effective both in } \\
\text { chemosensitive and } \\
\text { chemoresistant cell } \\
\text { lines }\end{array}$ & $\begin{array}{l}\text { INSM1 promoter- } \\
\text { driven SG }\end{array}$ & 63 \\
\hline $\begin{array}{l}\text { Mader R.M. } \\
\text { et al. }\end{array}$ & $\begin{array}{l}\text { CCL227 (with low and } \\
\text { Intermediate phenotypes) }\end{array}$ & In Vitro & $\begin{array}{l}\text { Effective with } 100 \% \\
\text { Activation }\end{array}$ & Adenoviral cosmids & 16 \\
\hline $\begin{array}{l}\text { Bondanza A. } \\
\text { et al. }\end{array}$ & Leukemia (mouse) & $\begin{array}{l}\text { In Vitro } \\
\text { In Vivo }\end{array}$ & $\begin{array}{l}\text { Effective with } \\
\text { IL-7 receptor } \\
\text { expression } \\
\text { (HA-1-, H-Y-) }\end{array}$ & $\begin{array}{l}\text { Herpes simplex virus } \\
\text { Thymidine kinase }(t k)\end{array}$ & 62 \\
\hline Xu Y. et al. & $\begin{array}{l}\text { Lewis Lung Cancer } \\
\text { A549 }\end{array}$ & $\begin{array}{l}\text { In Vitro } \\
\text { In Vivo }\end{array}$ & $\begin{array}{l}\text { Combination IL-12 and suicide gene } \\
\text { therapy enhances the antitumor effect } \\
\text { as a factor modifying the } \\
\text { tumor microenvironment }\end{array}$ & $\begin{array}{l}\text { AdCMV(-), AdhTERTHRP, } \\
\text { AdCMVmIL-12 }\end{array}$ & 61 \\
\hline Sia KC. et al. & HCC 26-1004 & $\begin{array}{l}\text { In Vitro } \\
\text { In Vivo }\end{array}$ & $\begin{array}{l}\text { Effective HSV-1 amplicon viral } \\
\text { vector and 5-FU administration }\end{array}$ & $\begin{array}{l}\text { HSV-1 amplicon viral } \\
\text { Vector coupled with yCD }\end{array}$ & 17 \\
\hline LiS. et al. & C17.2 NSC line & $\begin{array}{l}\text { In Vitro } \\
\text { In Vivo }\end{array}$ & ATRA enhanced the HSV-tk/GCV & HSVtk/GCV & 45 \\
\hline Finocchiaro & sarcoma & In Vivo & Effective & Lipid-complexed plasmid & 57 \\
\hline
\end{tabular}




\begin{tabular}{|c|c|c|c|c|c|}
\hline M.E.L. et al. & & & $\begin{array}{l}\text { Microenvironment } \\
\text { Control and } \\
\text { Distant metastasis }\end{array}$ & $\begin{array}{l}\text { Bearing IFN- } \beta \text { and suicide } \\
\text { genes co-administered with } \\
\text { ganciclovir (ISG) }\end{array}$ & \\
\hline $\begin{array}{l}\text { Leng A. } \\
\text { et. al. }\end{array}$ & $\begin{array}{l}\text { Human colon carcinoma } \\
\text { (Lovo) cell line }\end{array}$ & $\begin{array}{l}\text { In Vitro } \\
\text { In Vivo }\end{array}$ & $\begin{array}{l}\text { Anti-VEGF-A- } \\
\text { Suicide gene therapy }\end{array}$ & 5-FC, CPNP-shVEGF-CDTK & 59 \\
\hline Liu T. et. al. & $\begin{array}{l}\text { SGC7901 human gastric } \\
\text { Cancer cell line }\end{array}$ & $\begin{array}{l}\text { In vitro } \\
\text { In Vivo }\end{array}$ & $\begin{array}{l}\text { Anti-VEGF- } \\
\text { Suicide gene therapy }\end{array}$ & $\begin{array}{l}\text { 5-FC, triple gene vector } \\
\text { Expressing VEGF-shRNA and } \\
\text { fusion suicide gene } \\
\text { yCDglyTK delivered by CPNPs }\end{array}$ & 60 \\
\hline Finzi et. al. & $\begin{array}{l}\text { Human HT29 and murine } \\
\text { DHDK } 12 \text { pro-b }\end{array}$ & $\begin{array}{l}\text { In Vitro } \\
\text { In Vivo }\end{array}$ & $\begin{array}{l}\text { MTX, aphidicolin } \\
\text { and ara-C. The rate of apoptosis } \\
\text { increased two-fold in MTX-treated DHDK12 } \\
\text { cells after treatment with GCV. }\end{array}$ & HSVtk-GCV & 40 \\
\hline Niu H. et. al. & VX2 liver cancer & In Vivo & $\begin{array}{l}\text { Effective with lipiodol } \\
\text { embolism and WTp53 }\end{array}$ & $\begin{array}{l}\text { TK/CD plus intraperitoneal } \\
\text { Injection of GCV at } 100 \mathrm{mg} /(\mathrm{kg} . \mathrm{d}) \\
\text { and } 5-\mathrm{FC} \text { at } 500 \mathrm{mg} /(\mathrm{kg} . \mathrm{d})\end{array}$ & 43 \\
\hline $\begin{array}{l}\text { Marukawa } \\
\text { Y. et. al. }\end{array}$ & $\mathrm{HCC}$ & $\begin{array}{l}\text { In vitro } \\
\text { In Vivo }\end{array}$ & $\begin{array}{l}\text { Effective Mac-1, CD4, } \\
\text { CD8a-positive and TNF } \\
\text { increase }\end{array}$ & $\begin{array}{l}\text {-HSV-tk/GCV and MCP-1 } \\
\text {-rAd harboring human } M C P-1 \\
\text { and the membrane-spanning } \\
\text { domain of the tumor cell surface }\end{array}$ & 44 \\
\hline $\begin{array}{l}\text { Kosaka H. } \\
\text { t. al. }\end{array}$ & $\begin{array}{l}\text { 9L rat glioma cells and } 293 \\
\text { cells }\end{array}$ & $\begin{array}{l}\text { In vitro } \\
\text { In Vivo }\end{array}$ & $\begin{array}{l}\text { MSC-EGFP or } \\
\text { MSC-CD-5-FC resulted in } \\
\text { significant prolongation of survival }\end{array}$ & $\begin{array}{l}\text { AdexCAEGFP } \\
\text { AdexCACD }\end{array}$ & 55 \\
\hline $\begin{array}{l}\text { Schmidt M. } \\
\text { et. al. }\end{array}$ & $\begin{array}{l}\text { Head and Neck squamous } \\
\text { carcinoma cell line FADU }\end{array}$ & In Vitro & $\begin{array}{l}\text { Effective with deletion } \\
\text { Mutant of ETA as a } \\
\text { Target gene }\end{array}$ & Gene Switch System & 52 \\
\hline $\begin{array}{l}\text { Cottin S. } \\
\text { et. al. }\end{array}$ & Glioblastoma & In Vitro & $\begin{array}{l}\text { Effective against } \mathrm{C} \times 43 \\
\text { cytoplasmic localization }\end{array}$ & $\begin{array}{l}\text { Lentiviral delivery of } \\
\text { HSV-tk/GCV }\end{array}$ & 56 \\
\hline $\begin{array}{l}\text { Kakinoki K. } \\
\text { et. al. }\end{array}$ & $\mathrm{HCC}$ & $\begin{array}{l}\text { In vitro } \\
\text { In Vivo }\end{array}$ & $\begin{array}{l}\text { Effective against } \\
\text { metastasis and control } \\
\text { of microenvironment }\end{array}$ & $\begin{array}{l}\text { CCL2/MCP-1 } \\
\text { HSV-tk/GCV }\end{array}$ & 65 \\
\hline Sun X. et. al. & $\begin{array}{l}\text { R3327-AT rat prostate } \\
\text { Carcinoma cells }\end{array}$ & $\begin{array}{l}\text { In Vitro } \\
\text { In Vivo }\end{array}$ & $\begin{array}{l}\text { Effective against } \\
\text { hypoxic cells }\end{array}$ & $\begin{array}{l}\text { Bifunctional cytosine } \\
\text { deaminase (CD) and } \\
\text { uracil phosphoribosyltransferase } \\
\text { (UPRT) with 5-FC and } \\
\text { radiotherapy }\end{array}$ & 64 \\
\hline $\begin{array}{l}\text { Amano S. } \\
\text { et. al. }\end{array}$ & C6 glioma cells & $\begin{array}{l}\text { In Vitro } \\
\text { In Vivo }\end{array}$ & $\begin{array}{l}\text { Safety evaluation of the } \\
\text { Stem cell therapy in brain } \\
\text { tissue }\end{array}$ & Rat MSCtk/GCV & 67 \\
\hline $\begin{array}{l}\text { Zhao Y. } \\
\text { et. al. }\end{array}$ & U87 glioma and H4 cells & $\begin{array}{l}\text { In Vitro } \\
\text { In Vivo }\end{array}$ & $\begin{array}{l}\text { Effective as cellular } \\
\text { Vehicle for targeted } \\
\text { suicide gene therapy }\end{array}$ & $\begin{array}{l}\text { Tumor-tropic neural stem cells, } \\
\text { HSV-tk/GCV }\end{array}$ & 75 \\
\hline $\begin{array}{l}\text { Wang C. } \\
\text { et. al. }\end{array}$ & NCI-H460-GFP cells & $\begin{array}{l}\text { In Vitro } \\
\text { In Vivo }\end{array}$ & $\begin{array}{l}\text { Effective brain metastasis } \\
\text { treatment }\end{array}$ & $\begin{array}{l}\text { NSC line expressing } \\
\text { CD and TK }\end{array}$ & 53 \\
\hline Yin X. et. al. & $\begin{array}{l}\text { Bladder cancer with } \\
\text { N-methyl-nitrosourea } \\
\text { perfusion }\end{array}$ & $\begin{array}{l}\text { In Vitro } \\
\text { In Vivo }\end{array}$ & $\begin{array}{l}\text { Effective both in extrisinc } \\
\text { and intrisinc papoptosis } \\
\text { pathways }\end{array}$ & BI-HSV-tk/GCV & 51 \\
\hline $\begin{array}{l}\text { Cramer F. } \\
\text { et. al. }\end{array}$ & $\begin{array}{l}\text { SCLC: GLC16, DMS53 } \\
\text { and NCI-H69 and NSCLC } \\
\text { cancer lines: H1299 and } \\
\text { A549 }\end{array}$ & In Vitro & $\begin{array}{l}\text { Improved plasmid } \\
\text { nuclear delivery }\end{array}$ & $\begin{array}{l}\text { NFnB-DTS in an } \\
\text { YCD-YUPRT (SCD) }\end{array}$ & 41 \\
\hline $\begin{array}{l}\text { Duan X. } \\
\text { et. al. }\end{array}$ & $C-26$ & $\begin{array}{l}\text { In Vitro } \\
\text { In Vivo }\end{array}$ & $\begin{array}{l}\text { DMP Delivered Survivin- } \\
\text { T34A gene } \\
\text { DMP/S-T34A) } \\
\text { which induced apoptosis }\end{array}$ & $\begin{array}{l}\text { DOTAP and MPEG-PCL hybrid } \\
\text { micelles (DMP) }\end{array}$ & 71 \\
\hline $\begin{array}{l}\text { Zarogoulidis } \\
\text { P. et. al. }\end{array}$ & $\begin{array}{l}\text { Lewis lung cancer, } \\
\text { SCLC, NSCLC patients }\end{array}$ & $\begin{array}{l}\text { Animals } \\
\text { Humans }\end{array}$ & $\begin{array}{l}\text { Survival and malignant } \\
\text { pleural effusion control with higher } \\
\text { efficiency observed for SCLC. }\end{array}$ & Ad.CD+5-FC & 14 \\
\hline Yi B. et. al. & Review & Review & Review & Review & 50 \\
\hline $\begin{array}{l}\text { Qiu Y. } \\
\text { et. al. }\end{array}$ & $\begin{array}{l}\text { A549, 16HBE, SPC-A-1 } \\
\text { And NCI-H520 }\end{array}$ & In Vitro & $\begin{array}{l}\text { Specific CA-positive } \\
\text { Target gene expression }\end{array}$ & $\begin{array}{l}\text { CEA promoter and double suicide } \\
\text { genes TK and CD. } \\
\text { pCEA-TK/CD }\end{array}$ & 42 \\
\hline $\begin{array}{l}\text { Won Y. } \\
\text { et. al. }\end{array}$ & C6, U87, F98 and 9L & $\begin{array}{l}\text { In Vitro } \\
\text { In Vivo }\end{array}$ & $\begin{array}{l}\text { Tumor growth } \\
\text { Suppression and } \\
\text { locomotor function } \\
\text { maintenance }\end{array}$ & rPOA/HSV-tk/GCV & 46 \\
\hline $\begin{array}{l}\text { Akerstrom V. } \\
\text { et. al. }\end{array}$ & $\begin{array}{l}\text { Neuroendocrine tumors: } \\
\text { NCI-H69, NCI-H1155, } \\
\text { NCI-H727, DMS53, } \\
\text { U87MG, IMR-32, S-N-SH, } \\
\text { SK-N-BE(2), Y79, } \\
\text { WERI-Rb1, HeLa, ANC-1, } \\
\text { BEAS, RIN, D283 Med, } \\
\text { HepG2 }\end{array}$ & $\begin{array}{l}\text { In Vitro } \\
\text { In Vivo }\end{array}$ & $\begin{array}{l}\text { Enhanced antitumor } \\
\text { activity over the RSV } \\
\text { control }\end{array}$ & $\begin{array}{l}\text { INSM1 promoter, } \\
\text { HSV-tk to generate Ad-K5 virus }\end{array}$ & 47 \\
\hline
\end{tabular}




\begin{tabular}{|c|c|c|c|c|c|}
\hline Lu M. et. al. & Prostate & Human & $\begin{array}{l}\text { Initiated and recruiting at the time of } \\
\text { publication }\end{array}$ & $\begin{array}{l}\text { Replication-Competent } \\
\text { Adenovirus- mediated suicide } \\
\text { gene therapy }\end{array}$ & 48 \\
\hline Ma S. et. al. & $\begin{array}{l}\text { MCF-7 and MDA-MB-231 } \\
\text { Breast cell lines }\end{array}$ & $\begin{array}{l}\text { In Vitro } \\
\text { In Vivo }\end{array}$ & $\begin{array}{l}\text { Effective antitumor } \\
\text { control }\end{array}$ & $\begin{array}{l}\text { Drosophila melanogaster } \\
\text { (Dm-dNK) }\end{array}$ & 49 \\
\hline $\begin{array}{l}\text { Preuss E. } \\
\text { et. al. }\end{array}$ & $\begin{array}{l}\text { G62 human glioblastoma cell } \\
\text { Line, A549 human lung } \\
\text { Carcinoma, SW620 human } \\
\text { Colorectal adenocarcinoma } \\
\text { Cell line and IPC298 } \\
\text { Human Melanoma cell line }\end{array}$ & $\begin{array}{l}\text { In Vitro } \\
\text { In Vivo }\end{array}$ & $\begin{array}{l}\text { Continuous complete } \\
\text { remission }\end{array}$ & TK.007 novel suicide gene & 86 \\
\hline Ahn Y. et. al. & $\begin{array}{l}\text { CT26 murine colon } \\
\text { adenocarcinoma cells and } \\
\text { AGS human gastric } \\
\text { adenocarcinoma cells }\end{array}$ & $\begin{array}{l}\text { In Vitro } \\
\text { In Vivo }\end{array}$ & $\begin{array}{l}\text { Effective combination } \\
\text { Suicide immune therapy }\end{array}$ & $\begin{array}{l}\text { shRNA-lentivirus } \\
\text { and Ad5.CMV.HSV.tk }\end{array}$ & 39 \\
\hline $\begin{array}{l}\text { Gruber C. } \\
\text { et. al. }\end{array}$ & SCC & $\begin{array}{l}\text { In Vitro } \\
\text { In Vivo }\end{array}$ & $\begin{array}{l}\text { Efficient transfection of } \\
\text { RDEB SCC }\end{array}$ & $\mathrm{SLO}=\mathrm{PTM}$ & 87 \\
\hline Luo X. et. al. & $\begin{array}{l}\text { SGC7901 human gastric } \\
\text { Cancer cell lines }\end{array}$ & $\begin{array}{l}\text { In Vitro } \\
\text { In Vivo }\end{array}$ & $\begin{array}{l}\text { Higher efficiency with } \\
\text { double suicide gene } \\
\text { therapy } \mathrm{CD} / \mathrm{TK}\end{array}$ & $\begin{array}{l}\text { Double suicide gene therapy } \\
\text { Ad-survivin/GFP and } \\
\text { Ad-survivin/CD/TK }\end{array}$ & 70 \\
\hline $\begin{array}{l}\text { Freytag S. O. } \\
\text { et. al. }\end{array}$ & Prostate cancer & Human & $\begin{array}{l}\text { Transgene expression } \\
\text { up to } 3 \text { weeks, PSA } \\
\text { decline, Acute urinary } \\
\text { and gastrointestinal } \\
\text { toxicities }\end{array}$ & $\begin{array}{l}\text { Cytosine deaminasa(CD)/herpes } \\
\text { simplexvirus thymidine kinase } \\
\text { (HSV-1 TK) and 3D-CRT }\end{array}$ & 81 \\
\hline $\begin{array}{l}\text { Pandha H.S. } \\
\text { et. al. }\end{array}$ & Breast cancer & Human & $\begin{array}{l}\text { Efficient selectivity } \\
\text { against } e r b \text {-2 }\end{array}$ & $\begin{array}{l}\text { Therapeutic cassette that contains } \\
\text { the Escherichia coli cytosine } \\
\text { deaminase gene drivan by the } \\
\text { tumor-specific erb-2 promoter }\end{array}$ & 82 \\
\hline Li N. et. al. & HCC cancer & Human & Recurrence free survival & Adjuvant ADV-TK & 80 \\
\hline Voges J. et. al. & Glioblastoma & Human & $\begin{array}{l}\text { Inhomogeneity of tissue } \\
\text { formulation distribution }\end{array}$ & HSV-1-tk liposomal vector & 77 \\
\hline $\begin{array}{l}\text { Nasu Y. } \\
\text { et. al. }\end{array}$ & Prostate & Human & $\begin{array}{l}\text { No serum cytokine } \\
\text { changes after treatment, } \\
\text { decreased PSA values, } \\
\text { Increased } \\
\text { CD } 8+\text { /HLA-DR+ } \\
\text { This study confirmed the } \\
\text { safety profile at the surrogate marker } \\
\text { of HSV-tk gene therapy. }\end{array}$ & Ad.HSV-tk/GCV & 78 \\
\hline $\begin{array}{l}\text { Rainov N.G. } \\
\text { et. al. }\end{array}$ & Glioblastoma & Human & $\begin{array}{l}\text { Surgical resection and } \\
\text { Radiotherapy or standard } \\
\text { therapy plus adjuvant } \\
\text { gene therapy during } \\
\text { surgery. Progression-free } \\
\text { median survival in the gene group } \\
\text { was } 180 \text { days compared with } 1 \\
83 \text { days of control group }\end{array}$ & RV-HSV-tk/GCV & 76 \\
\hline Xu F. et. al. & Head and Neck & Human & Local response & Intratumoral RV-HSV-tk/GCV & 79 \\
\hline $\begin{array}{l}\text { Nemunaitis J. } \\
\text { et. al. }\end{array}$ & Refractory cancer patients & Human & $\begin{array}{l}\text { Salmonella bacterium } \\
\text { can be utilized as a } \\
\text { delivery vehicle of the } \\
\text { cytosine deaminase gene } \\
\text { to malignant tissue with low dose } \\
3 \times 10^{7} \mathrm{CFU} / \mathrm{m}^{2} \text { efficiently. }\end{array}$ & TAPET-CD & 84 \\
\hline $\begin{array}{l}\text { Freytag S. O. } \\
\text { et. al. }\end{array}$ & Pancreas & Human & $\begin{array}{l}\text { Augments radiotherapy } \\
\text { treatment of pancreatic } \\
\text { cancer without excessive } \\
\text { toxicity }\end{array}$ & $\begin{array}{l}\text { Ad5-yCD/mutTKSR39rep-ADP } \\
\text { HSV-1 TK } \\
\text { SR39 }\end{array}$ & 83 \\
\hline
\end{tabular}

INSM1; insulinoma-associated 1 gene, IFN- $\boldsymbol{\beta}$; Interferon- $\beta$, GCV; ganciclovir, CEA; Carcinoembryonic antigen, ELISA; Enzyme-linked immuno sorbent assay, IL-7; Interleukin-7, wtCPE; wild type Clostridium perfringens enterotoxin, optCPE; translation-optimised Clostridium perfringens enterotoxin, IL-12; interleukin-12, HSV-1; herpes simplex virus-1, 5-FC; 5-Fluorocytosine, VEGF; vascular endothelial growth factor, CPNPs; bioresorbable calcium phosphate nanoparticles, HSV-tk; herpes simplex virus-thymidine kinase, yCDglyTK; fusion gene therapy of cytosine deaminase and thymidine kinase, Mac-1; Macrophage-1 antigen, CD4+; T lymphocytes, referring to those that carry the CD4 antigen, CD8+; T lymphocytes, referring to those that carry the CD8 antigen, CC12; chemokine (C-C motif) ligand 2 [Homo sapiens (human), rAd; recombinant adenovirus, MCP-1; Monocyte chemoattractant protein-1, ETA; ETA receprtors, WTp53; wild type p53, Cx43; integral membrane protein of the connexin family, alpha-type (group II) subfamily, MSC; mesenchymal stem cells, AdexCAEGFP; MSC- adenovirus carrying either enhanced green fluorescent protein gene, AdexCACD; MSC- cytosine deaminase gene, UPRT; uracil phosphoribosyltransferase, NSCs; neural stem cells, hTERT; human telomerase reverse transcriptase, HRP; expressing horseradich peroxidase, IAA; idole-3-acetic acid, CArG; Smooth muscle alpha-actin CArG elements, BI; Bifidobacterium infantis, VSV; vesicular stomatitis virus, NFnB; nuclear factor B, DOTAP; N-[1-(2,3-dioleoyloxy)propyl]-N,N,N-trimethylammonium methyl sulfate, MPEG-PCL; monomethoxy poly(ethylene glycol)-poly(3-caprolactone, DMP; DOTAP-MPEG-PCL, KDR; kinase insert domain receptor, AFP; a-fetoprotein, rPOA; poly (oligo-D-arginine), DM; Drosophila melanogaster,PET; positronemission tomography, Ad5.CMV.HSV.tk; adenoviruse 5 harboring the herpes simplex virus thymidine kinase gene, SLO=PTM; toxin Streptolysin O-3 pre-trans-splicing molecules, RDEB-SCC; recessive dystrophic epidermolysis bullosa squamous cell carcinoma, PTM screen; 3 ' pre-trans-splicing molecules, PSA; prostate specific antigen, GDEPT; gene-directed enzyme pro-drug therapy, TAPET-CD; pCVD442-ms b B-VNP20009 


\section{Results}

\section{Results of cell viability and apoptosis analysis}

Flow cytometry showed that ad.CD-5-FC + ancotil treatment induced apoptosis in both cell lines after $4 \mathrm{~h}$ and $8 \mathrm{~h}$ as determined by 7-AAD and Annexin $\mathrm{V}$ staining (Table 3). At these time-points, sensitivity to $0.2,0.8$ and $1.2 \mathrm{mg}$ ancotil was similar in both cell lines. However, the $24 \mathrm{~h}$ measurement for cell cytometry for all the doses revealed that cell viability was increased for retinal cell line, whereas ad.CD-5-FC + ancotil treatment continued to induce apoptosis for melanoma cell line. The results of 7-AAD and Annexin $\mathrm{V}$ staining were also confirmed by trypan blue assay. (Table 2.) Comparison among the time-points revealed that $1.2 \mathrm{ml}$ of ancotil increased the number of viable cells by $87 \%$ after $8 \mathrm{~h}$ to $95 \%$ after $24 \mathrm{~h}$ in retinal cell line, whereas in melanoma cell line viable cells were decreased by $78 \%$ after $8 \mathrm{~h}$ to $75 \%$ after $24 \mathrm{~h}$. Similar observations were revealed for the other doses of ancotil.

Table 2: cell viability by trypan blue counting.

\begin{tabular}{lllllll}
\hline & \multicolumn{3}{l}{ Melanoma cell line } & \multicolumn{3}{l}{ Retinal cell line } \\
\hline $\begin{array}{l}\text { Concentrations/Time } \\
\text { points }\end{array}$ & $4 \mathrm{~h}$ & $8 \mathrm{~h}$ & $24 \mathrm{~h}$ & $4 \mathrm{~h}$ & 8 & $24 \mathrm{~h}$ \\
$0.2 \mathrm{ml}$ ancotil & $80 \%$ & $80 \%$ & $78 \%$ & $82 \%$ & $85 \%$ & $93 \%$ \\
$0.8 \mathrm{ml}$ ancotil & $75 \%$ & $75 \%$ & $75 \%$ & $80 \%$ & $85 \%$ & $90 \%$ \\
$1.2 \mathrm{ml}$ ancotil & $78 \%$ & $78 \%$ & $75 \%$ & $80 \%$ & $87 \%$ & $95 \%$ \\
\hline
\end{tabular}

Table 3. Cell viability with 7-AAD and Annexin V/PI.

\begin{tabular}{|c|c|c|c|c|c|c|c|c|c|}
\hline & & \multicolumn{8}{|c|}{ 7-AAD } \\
\hline & & \multicolumn{2}{|c|}{$4 \mathrm{H}$} & \multicolumn{2}{|c|}{$8 \mathrm{H}$} & \multicolumn{2}{|c|}{$24 \mathrm{H}$} & & \\
\hline & & CELLS\% & VIABILITY\% & CELLS \% & VIABILITY\% & CELLS\% & $\begin{array}{l}\text { VIABILIT } \\
\%\end{array}$ & & \\
\hline \multirow[t]{3}{*}{ R CELLS } & 0.2 & 36.7 & 78.9 & 50.7 & 74.7 & 85.1 & 89.8 & & \\
\hline & 0.8 & 20 & 71.4 & 56.4 & 70.1 & 65.4 & 82.1 & & \\
\hline & 1.2 & 31.1 & 69.3 & 55 & 77.9 & 82.5 & 86.1 & & \\
\hline \multirow[t]{6}{*}{ M CELLS } & 0.2 & 53.7 & 82.6 & 81.3 & 79.5 & 76.6 & 89.3 & & \\
\hline & 0.8 & 56.3 & 80.1 & 79.5 & 85.7 & 83 & 85.9 & & \\
\hline & 1.2 & 55.5 & 79.5 & 79.2 & 83.9 & 75.9 & 83.9 & & \\
\hline & & \multicolumn{8}{|c|}{ ANNEXIN V/PI } \\
\hline & & \multicolumn{2}{|c|}{$4 \mathrm{H}$} & \multicolumn{3}{|c|}{$8 \mathrm{H}$} & \multicolumn{3}{|c|}{$24 \mathrm{H}$} \\
\hline & & APOPTOTIC & VIABILITY\% & CELLS $\%$ & АРОРТОTIC & VIABILITY\% & CELLS\% & APOPTOTIC & VIABILITY\% \\
\hline \multirow[t]{3}{*}{ R CELLS } & 0.2 & 20.7 & 58.2 & 43.7 & 33 & 57.5 & 65.4 & 20.3 & 72.7 \\
\hline & 0.8 & 30.1 & 48.7 & 28.7 & 43.9 & 41.8 & 42.3 & 36.8 & 44.6 \\
\hline & 1.2 & 38.5 & 46 & 36.4 & 38.2 & 50.2 & 57 & 28.3 & 62.9 \\
\hline \multirow[t]{3}{*}{ M CELLS } & 0.2 & 5.1 & 66.3 & 83.4 & 85.2 & 0.7 & 75.7 & 1.6 & 80.7 \\
\hline & 0.8 & 3.3 & 65 & 59.6 & 3 & 78.5 & 74.4 & 0.9 & 82.2 \\
\hline & 1.2 & 3.7 & 72.8 & 55.5 & 2.9 & 73.3 & 73.9 & 1.9 & 75.1 \\
\hline
\end{tabular}

\section{Discussion}

Currently there is need for more systems activating more pro-drugs. Therefore the thymidine-active mutant of dCK, dCK.DM.S74E was created which activates multiple pro-drugs such as; BVdU, LdUNAs and LdT. This system has the ability to sensitize and re-sensitize tumors to chemotherapeutic agents. Moreover, it can silmutaneously activate more than one drug and prevents multi drug resistence. ${ }^{66}$ Previous studies have investigated suicide gene therapy as a local treatment to the tumor site without any remarkable histological adverse effects in lung cancer patients, and in glioma cancer cell lines 14,67 . Recently suicide gene therapy was applied for melanoma with (HSV-tk), which converts ganciclovir (GCV). ${ }^{58}$ However, loco-regional admin- istration is not always possible and therefore the "Trojan horse" approach has been investigated. In the study by Zhao Y. et. al. (2012) the tumor-tropic neural stem cells (NSCs) derived from HES1 human embryonic stem cell line had the ability to migrate from the injection site (vein systemic administration) or intracranial to the intracranial glioma xenografts. A baculovirus vector was used to insert the HSV-tk suicide gene into the cells. A concentration of ganciclovir was also administered in order for an amount of the drug to be present locally for the suicide system to act. A prolonged transgene expression was observed for three weeks. This study presented where a sustain release system of suicide gene therapy could be used as a future concept. ${ }^{54}$ The same concept has been also applied with MSC in a hepatocellular (HCC) model 68. Additionally, Wang C. et al. ${ }^{69}$ investigated NSCs (F3) 
as dual suicide gene therapy with cytosine deaminase (CD) and Thymidine Kinase (TK) creating the NSC-F3.CD-TK. Enhanced antitumor activity was observed against lung cancer metastasis in comparison to single suicide gene therapy. Dual suicide gene therapy was also used in lung cancer cell lines with a carcinoembryonic antigen (CEA) promoter with TK and CD constructing the pCEA-TK/CD ${ }^{42}$. Dual suicide gene therapy was also investigated with surviving promoter with Ad-survivin/GFP and Ad-survivin/CD/TK. ${ }^{70}$ A very important parameter that has to be presented is the fact that the pro-drug has to be already diffused within the target tissue prior the administration of the adenovirus in order for the therapy to be efficient. Further investigation of transporting vehicles has led to the development of nanoparticles. ${ }^{12}$ In the study by Duan X. et al. ${ }^{71}$ the novel gene transfection cationic self-assembled DOTAP and MPEG-PCL hybrid micelles (DMP) was investigated. Less toxicity was observed when compared to the polymer Polyethyleneimine (PEI) with $25 \mathrm{kDa}$. The DMP delivered efficiently the urvivin-T34 gene (S-T34A) to treat C-26 colon cancer cell lines.

Currently there are very few clinical studies in patients with suicide gene therapy and therefore every effort is welcomed. ${ }^{14,72-85}$ Recently the first clinical trial design for early prostate cancer was published and another one with extensive stage has already been initiated. 48,81

Moreover, novel suicide genes such as the TK.007, have already been introduced and demonstrated efficiency in several cancer cell lines (G62 human glioblastoma cell line, A549 human lung carcinoma, SW620 human colorectal adenocarcinoma cell line and IPC298 human melanoma cell line) ${ }^{86}$. In the study by Gruber C. et al. ${ }^{87}$ the efficiency of 3 ' pre-trans-splicing molecules (PTM) was investigated and high efficiency was observed against highly malignant tumors. In the study by Di Stasi et al. ${ }^{88}$, the inducible caspase 9 (iCasp9) gene was investigated. It was applied to children who developed graft-vs.-host disease (GVHD) by donor lymphocytes; it was observed that the process was reversed with the novel suicide gene therapy.

Using promoters as a method to target specific overexpressed pathways has been also used for; a) carcino-embryonic antigen (CEA) ${ }^{42}$, b) EGFR ${ }^{89}$, c) prostate specific antigen (PSA) ${ }^{90}$, e) transferrin receptor (TfR) ${ }^{91}$, d) cyclooxygenase (Cox) 92, f) Telomerase-hTERT ${ }^{93}$ and g) Cytokeratin 18 and $19{ }^{94}$. We suggest that a future method of application could be made with local injections or instillation with eye droplets.

\section{Conclusions}

Suicide gene therapy with ad.CD-5-FC could be used as a local treatment for primary or metastatic melanoma. We observed safety for the therapeutic dosages of 5-FC from $0.2 \mathrm{mg}$ up to $1.2 \mathrm{mg}$ for the normal retinal cells lines while the same dosages were lethal for the human melanoma cell lines. Future studies in animals and clinical trials remain to elicit the in vivo safety and efficiency of this therapeutic application.

\section{Materials and Methods}

\section{Adenosine Cytosine Deaminase}

The Ad.CD used in this study was kindly donated by Dr. A.B. Deisseroth (Yale University School of Medicine, New Haven, US). This vector is a replication-incompetent recombinant adenoviral vector that contained the Escherichia coli CD gene in a L-plastine promoter-driven transcription unit ${ }^{95}$ Ad.CD was propagated in 293 cells (ATCC, Teddington, UK) and recovered 36 hours after infection by five cycles of freezing/thawing of the infected cells. All viral preparations were purified by $\mathrm{CsCl}$ density centrifugation, dialyzed, and stored in dialysis buffer $(10 \mathrm{mM}$ Tris $\mathrm{pH}$ $7.8,150 \mathrm{mM} \mathrm{NaCL}, 10 \mathrm{mM} \mathrm{MgCl} 2,10 \%$ glycerol) at $-70^{\circ} \mathrm{C}$ before use. Titers of the viral stocks were determined by plaque assay using 293 cells by standard methods. ${ }^{96}$

\section{Cell cultures and reagents}

HTB-70 (melanoma cell line, derived from metastatic axillary node) and CRL-2302 (human retinal epithelium) were purchased from ATCC LGC Standards. HTB-70 cells were isolated from a 24 year old female patient and CRL-2302 cells from a 19 year old male (http://www.lgcstandards-atcc.org). HTB-70 cells were cultured in Dulbecco's Modified Eagle's Medium (DMEM) culture medium (ATCC-30-2003) supplemented with 10\% Fetal Bovine Serum (FBS) (Biochrom S0115). CRL-2302 cells were cultured in DMEM (ATCC-30-2006) supplemented with 10\% FBS. Both cell lines were incubated at $37^{\circ} \mathrm{C}$ in a humidified atmosphere containing 5\% $\mathrm{CO}_{2} \cdot{ }^{97,98}$ Cell lines were cultured in Coming's tissue culture flasks (25 and 75 $\mathrm{cm}^{2}$ ) according to the manufacturer's protocol. After cultures reached confluence, cells were detached with trypsin (1:250) $2.5 \%$ (Biochrom L2133) and passaged. The indicated cell lines were seeded in $25 \mathrm{~cm}^{2}$ flasks at a seeding density of $0.7 \times 10^{6}$ cells. At confluence, (approximately $2.8 \times 10^{6}$ cells), adenovirus (85 $\mu$ l of Crude viral lysate -CVL, approximately 1-10pfu/cell) was added in both cell lines. The adenovirus vector was provided by Prof. A. Deisseroth, Yale University School of Medicine, and cultured in the research la- 
boratory of the Lung Tumor Research Section of the Pulmonary Dept. Aristotle Univ. Medical School. Cytopathic effect was observed only in melanoma cell lines after $36 \mathrm{~h}$ and then Ancotil ${ }^{\circledR} 2.5 \mathrm{~g} / 250 \mathrm{ml}$ (1 $\mathrm{g} / 00 \mathrm{ml}$ ) (5-Flucytosine) MEDA; Pharmaceuticals Ltd. UK was added in both cell lines at different concentrations $(0.2 \mathrm{ml}, 0.8 \mathrm{ml}$ and $1.2 \mathrm{ml})$. At indicated time-points (4h, $8 \mathrm{~h}$ and $24 \mathrm{~h})$ cell viability and apoptosis was measured.

\section{Trypan Blue Assay}

Trypan blue assay was applied to measure cell viability. Trypan blue dye can penetrate only porous, permeable membranes of lethally damaged (dead) cells, which is clearly detectable under optical microscopy. ${ }^{99}$ After adenovirus infection and ancotil treatment, both cell lines were trypsinized and collected, washed with PBS and suspended in complete culture medium. Then, $50 \mu \mathrm{l}$ of this cell suspension were added to $50 \mu \mathrm{L}$ of $0.04 \%$ trypan blue dye (Sigma Aldrich Corp.). This solution was maintained in room temperature for 2 minutes to allow trypan blue penetration and then viable and dead cells were counted in the hemocytometer under an inverted light microscope (Zeiss, West Germany). Cell viability was calculated by deducting the number of nonviable cells from the number of total cells. The number of cells obtained in the counting corresponded to $\mathrm{n} \times 104$ cells permilliliter of suspension. (Table 2.) (Figure 1.)

\section{Flow Cytometry}

Separation of dead and alive cells with 7-AAD staining (7-amino-actinomycin D)

7-Aminoactinomycin D (7-AAD) is a fluorescent chemical compound with a strong affinity for DNA. It is used as a fluorescent marker for DNA in fluores-

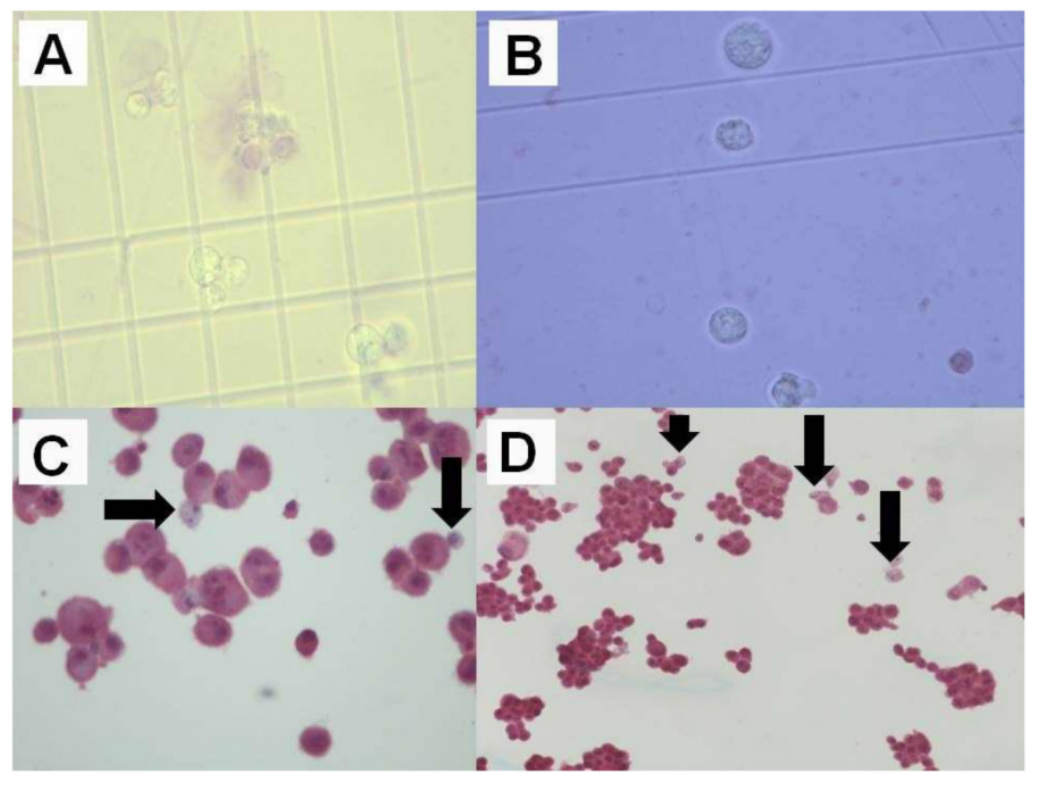

cence microscopy and flow cytometry. 7-AAD staining was purchased from Immunostep company (Spain) and the analysis of the samples was performed using BD FACSCalibur 4 colors, with CELLQUEST software (BECTON-DICKINSON USA). After adenovirus infection and ancotil treatment, both cell lines were trypsinized and collected, washed with PBS and suspended in complete culture medium. 100 $\mu \mathrm{L}$ of cell suspension (concentration 3000 to 5000 cells/ $\mu \mathrm{L}$ ) were added to $5 \mu \mathrm{L}$ of 7AAD staining. This solution was incubated for $10 \mathrm{~min}$ in a dark place at room temperature. Then it was diluted with $0.5 \mathrm{ml}$ of PBS and analyzed in the flow cytometer at indicated time-points (after 4h, 8h and 24h). (Table 3.) (Figures 2-10)

\section{Analysis of the apoptotic cells with ANNEXIN V/ PI}

Annexin V staining is used as a probe to detect cells that have expressed phosphatidylserine (PS) on the cell surface, an event found in apoptosis as well as other forms of cell death. Propidium iodide (PI) is used as a DNA stain for both flow cytometry, to evaluate cell viability or DNA content in cell cycle analysis 100 , and microscopy to visualize the nucleus and other DNA containing organelles. It can be used to differentiate necrotic, apoptotic and normal cells. The Annexin V kit used in this study was purchased from Immunostep company (Spain) and the analysis of the samples were performed in BD FACSCalibur 4 colors, with CELLQUEST software (BECTON-DICKINSON USA). After adenovirus infection and ancotil treatment, both cell lines were trypsinized and collected, washed with PBS and suspended in complete culture medium. $100 \mu \mathrm{l}$ of cell suspension (concentration 3000 to 5000 cells/ $\mu \mathrm{L}$ ) were added to $500 \mu \mathrm{L}$ of Annexin binding buffer. Then $5 \mu \mathrm{L}$ of Annexin V and $5 \mu \mathrm{L}$ PI were added to this solution and it was incubated for $15 \mathrm{~min}$ in a dark place at room temperature. Then it was analyzed in the flow cytometer at indicated time-points (after $4 \mathrm{~h}$, $8 \mathrm{~h}$ and 24h). (Table 3.) (Figures 2-10)

\section{5-Fluorocytosine}

The Ancotil ${ }^{\circledR} 2.5 \mathrm{~g} / 250 \mathrm{ml}(1 \mathrm{~g} / 00 \mathrm{ml})$ (5-Flucytosine) MEDA; Pharmaceuticals Ltd. UK was purchased and used for the experiment.

Figure I. A) Melanoma trypan blue $x$ 400, B) Retinal Trypan Blue $\times 400, C$ ) Melanoma cells plus adenovirus $\times 400$ (black arrows indicate the Ad.CD), D) Retinal cells plus adenovirus $\times 400$ (black arrows indicate the Ad.CD). 
A

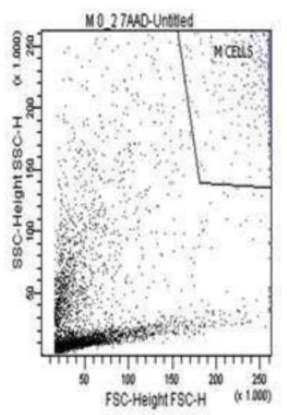

C

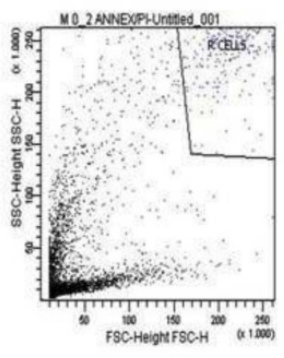

M 0,2 7AAD 4H

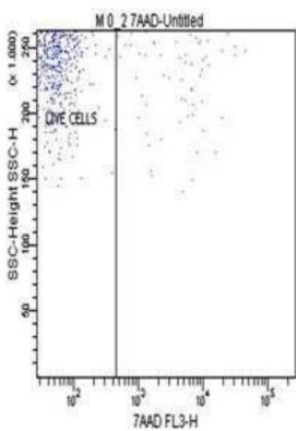

M 0,2 ANNEXIN V 4H

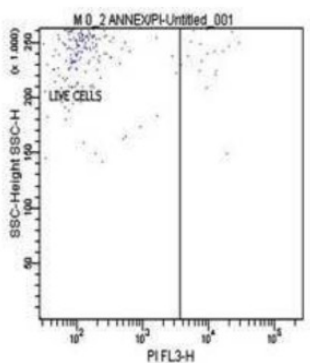

B

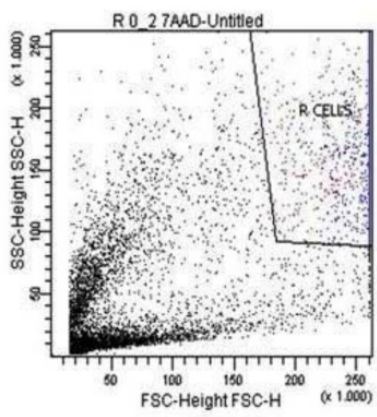

D

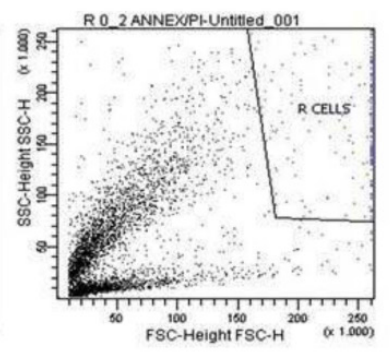

R 0,2 7AAD 4H

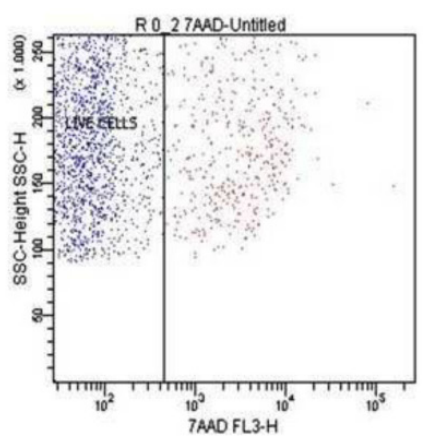

R 0,2 ANNEXIN V 4H

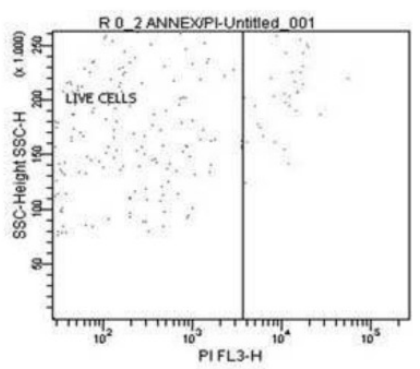

Figure 2. A) Melanoma cells $0.2 \mathrm{mg}$ ancotil and viability at 4 hours with 7-AAD, B) Retinal cells $0.2 \mathrm{mg}$ ancotil and viability at 4 hours with 7-AAD, C) Melanoma cell $0.2 \mathrm{mg}$ ancotil and viability at 4 hours with annexin, D) Retinal cells $0.2 \mathrm{mg}$ ancotil and viability at 4 hours with annexin.

A

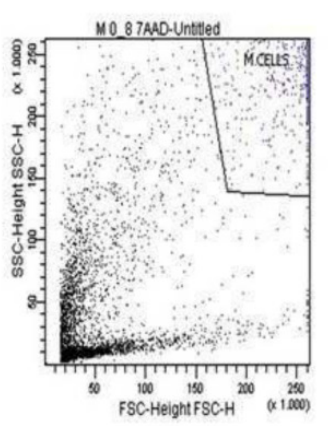

C

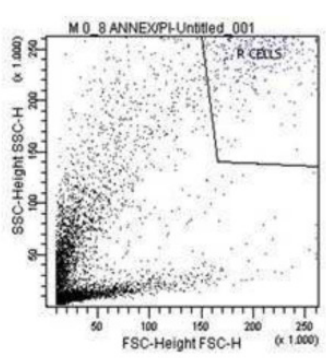

M 0,8 7AAD 4H

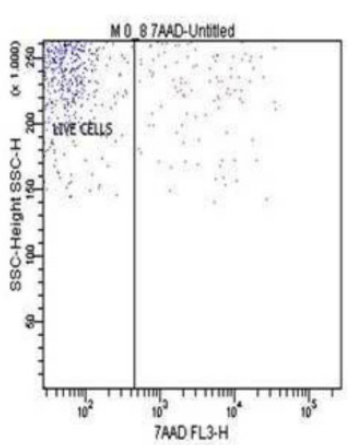

M 0,8 ANNEXIN V 4H

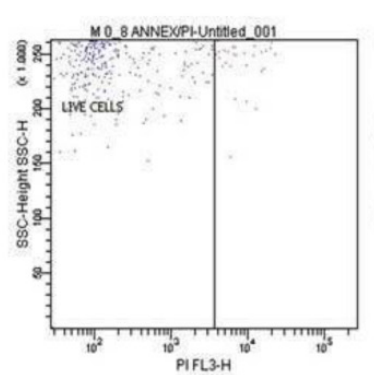

B

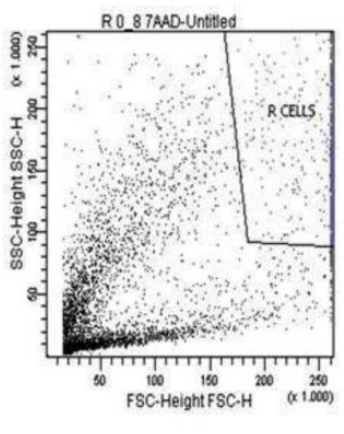

D

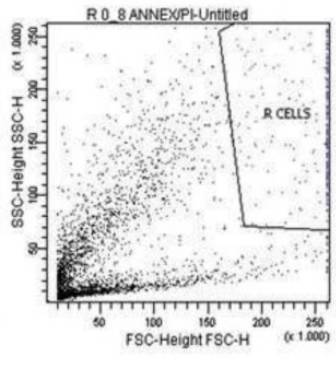

\section{R 0,8 7AAD 4H}

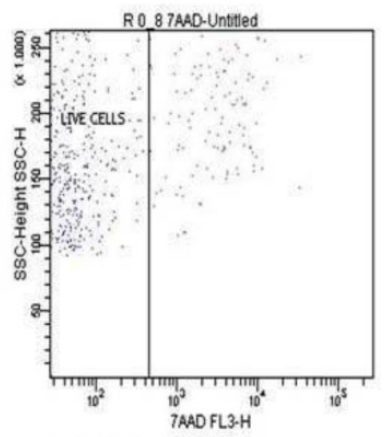

R 0,8 ANNEXIN V 4H

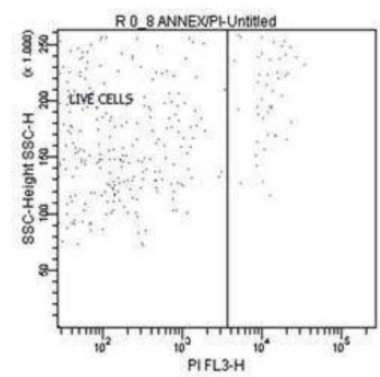

Figure 3. A) Melanoma cells $0.8 \mathrm{mg}$ ancotil and viability at 4 hours with 7-AAD, B) Retinal cells $0.8 \mathrm{mg}$ ancotil and viability at 4 hours with 7-AAD, C) Melanoma cell $0.8 \mathrm{mg}$ ancotil and viability at 4 hours with annexin, D) Retinal cells $0.8 \mathrm{mg}$ ancotil and viability at 4 hours with annexin. 
A

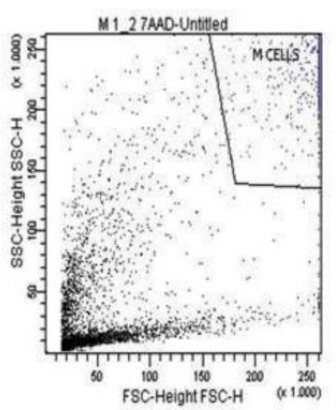

C

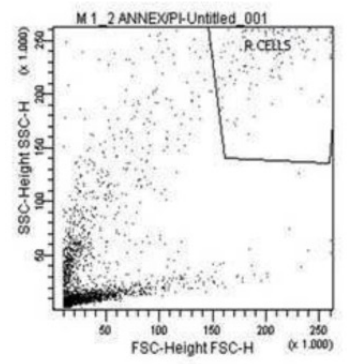

M 1,2 7AAD 4H

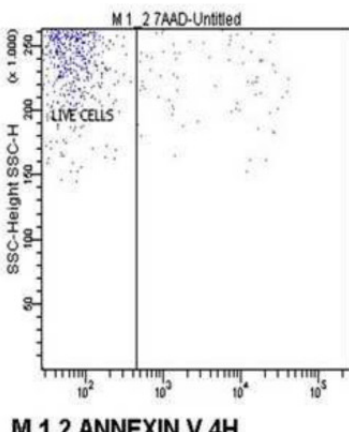

M 1,2 ANNEXIN V 4H

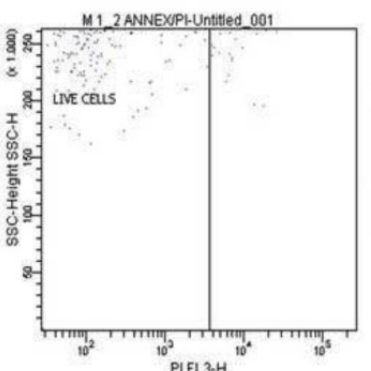

B

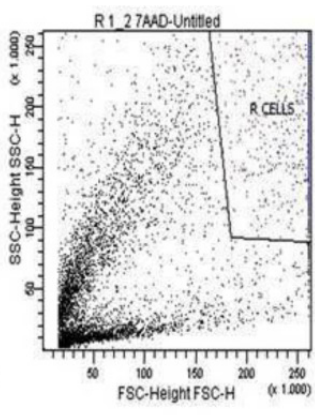

D

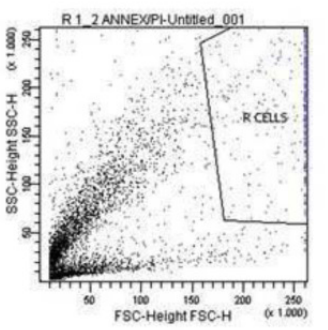

R 1,2 7AAD 4H

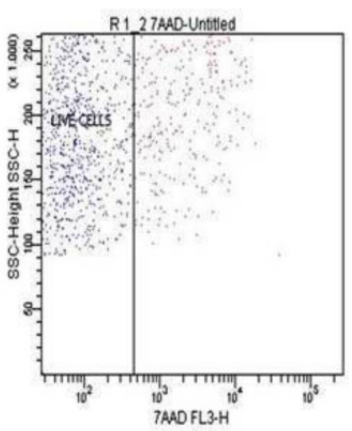

R 1,2 ANNEXIN V 4H

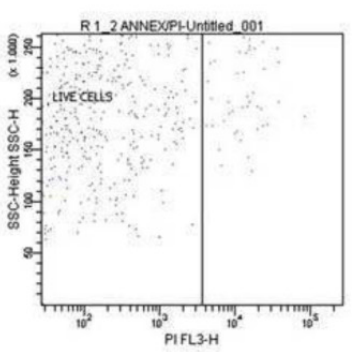

Figure 4. A) Melanoma cells $I .2 \mathrm{mg}$ ancotil and viability at 4 hours with 7-AAD, B) Retinal cells $I .2 \mathrm{mg}$ ancotil and viability at 4 hours with 7-AAD, C) Melanoma cell I.2mg ancotil and viability at 4 hours with annexin, D) Retinal cells $1.2 \mathrm{mg}$ ancotil and viability at 4 hours with annexin.

A

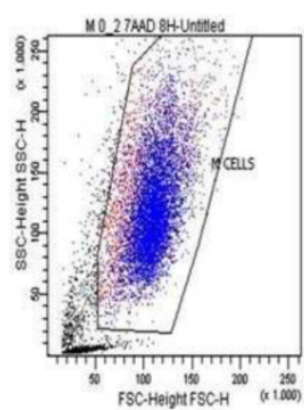

C

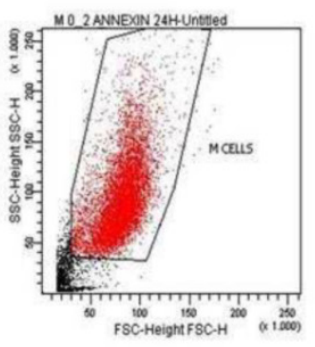

M 0,2 7AAD 8H

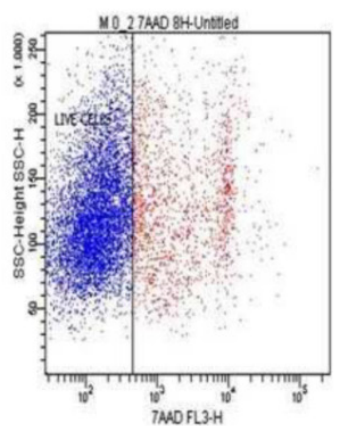

M 0,2 ANNEXIN V-PI 8H

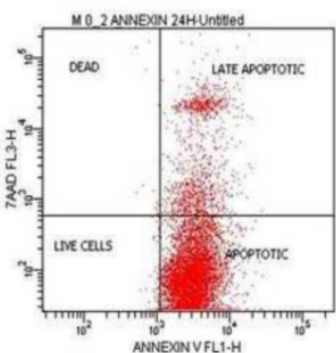

B

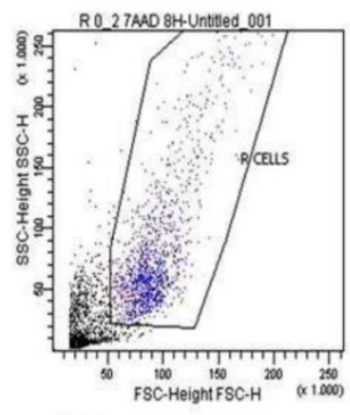

D

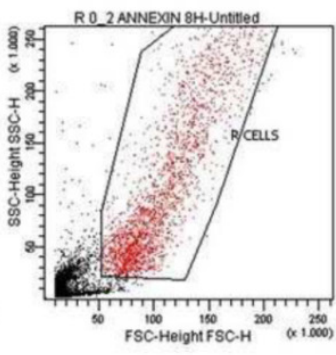

R 0,2 7AAD 8H

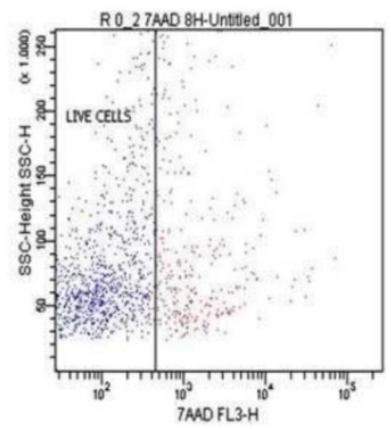

R 0,2 ANNEXIN V-PI 8H

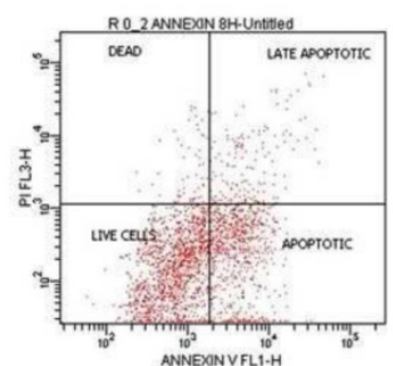

Figure 5. A) Melanoma cells $0.2 \mathrm{mg}$ ancotil and viability at 8 hours with 7-AAD, B) Retinal cells $0.2 \mathrm{mg}$ ancotil and viability at 8 hours with 7-AAD, C) Melanoma cell $0.2 \mathrm{mg}$ ancotil and viability at 8 hours with annexin, D) Retinal cells $0.2 \mathrm{mg}$ ancotil and viability at 8 hours with annexin. 
A

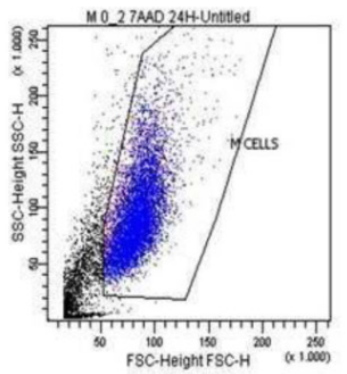

C

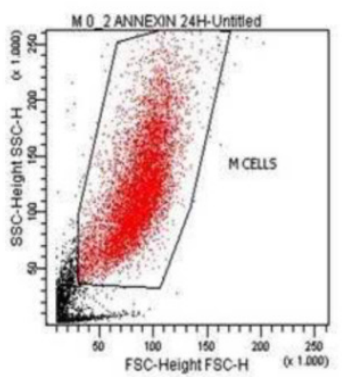

M 0,2 7AAD 24H

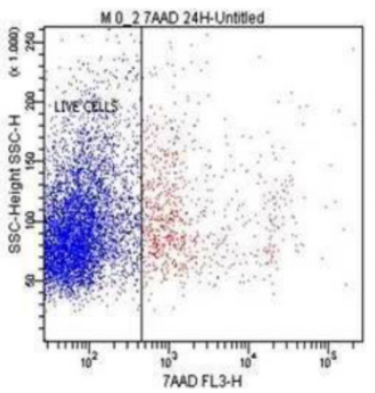

M 0,2 ANNEXIN V-PI 24H

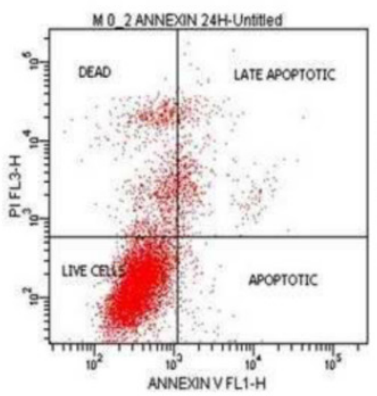

B

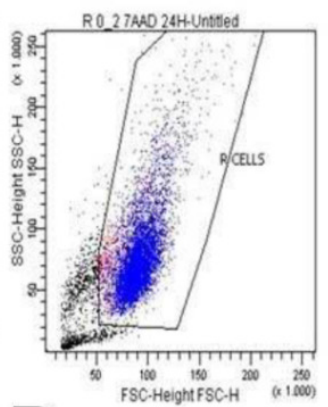

D

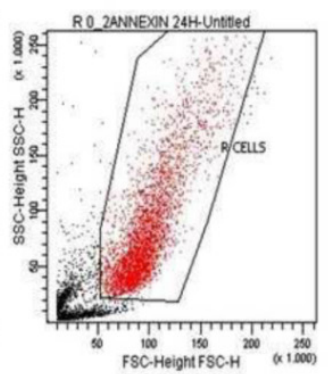

R 0,2 7AAD 24H
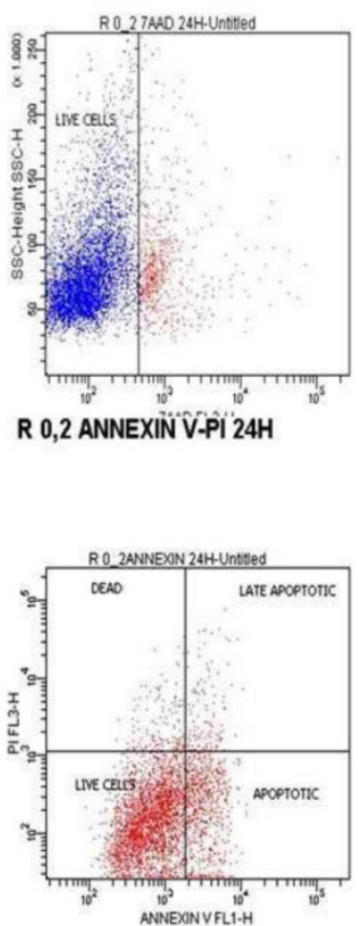

Figure 6. A) Melanoma cells $0.2 \mathrm{mg}$ ancotil and viability at 8 hours with 7-AAD, B) Retinal cells $0.2 \mathrm{mg}$ ancotil and viability at 8 hours with 7-AAD, C) Melanoma cell $0.2 \mathrm{mg}$ ancotil and viability at 8 hours with annexin, D) Retinal cells $0.2 \mathrm{mg}$ ancotil and viability at 8 hours with annexin.

A

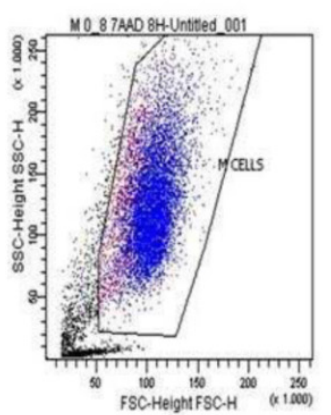

C

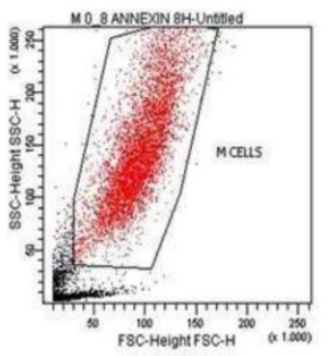

M 0,8 7AAD 8H

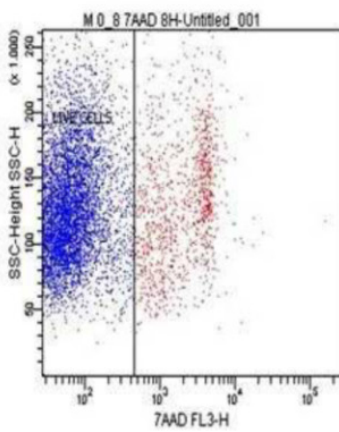

M 0,8 ANNEXIN V-PI 8H

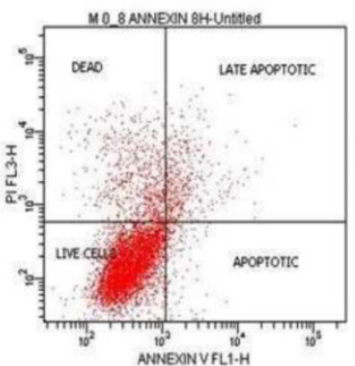

B

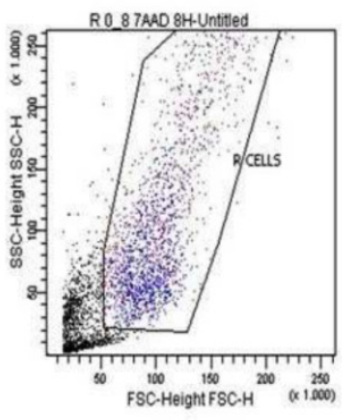

D

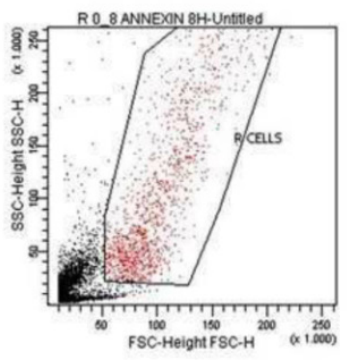

R 0,8 7AAD 8H

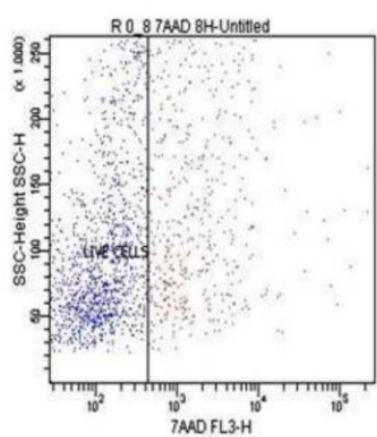

R 0,8 ANNEXIN V-PI 8H

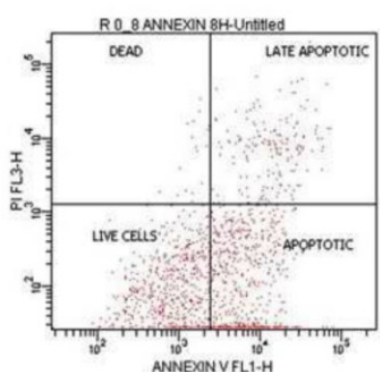

Figure 7. A) Melanoma cells $0.2 \mathrm{mg}$ ancotil and viability at 8 hours with 7-AAD, B) Retinal cells $0.2 \mathrm{mg}$ ancotil and viability at 8 hours with 7-AAD, C) Melanoma cell $0.2 \mathrm{mg}$ ancotil and viability at 8 hours with annexin, D) Retinal cells $0.2 \mathrm{mg}$ ancotil and viability at 8 hours with annexin. 
A

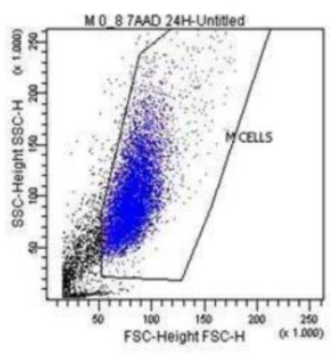

C

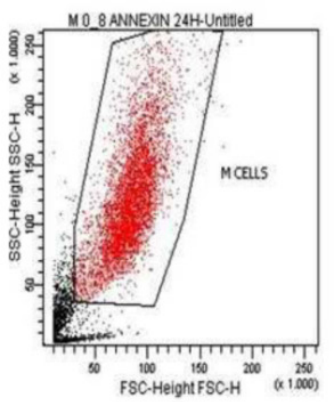

M 0,8 7AAD 24H

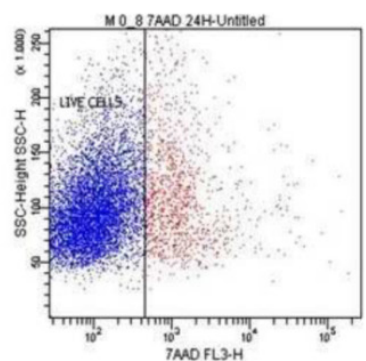

M 0,8 ANNEXIN V-PI 24H

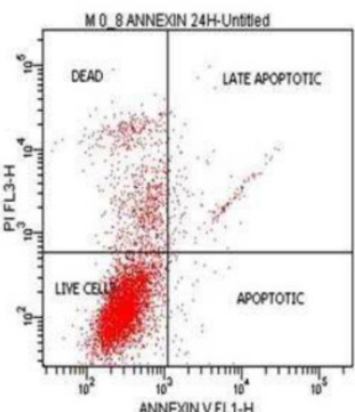

B

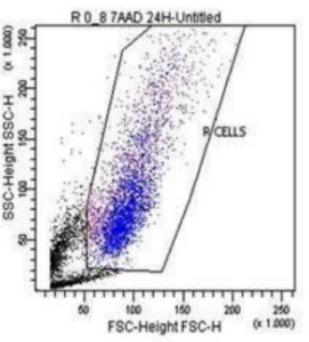

D

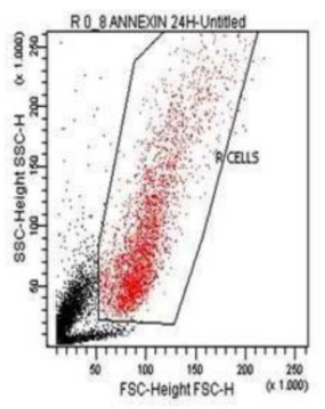

R 0,8 7AAD 24H

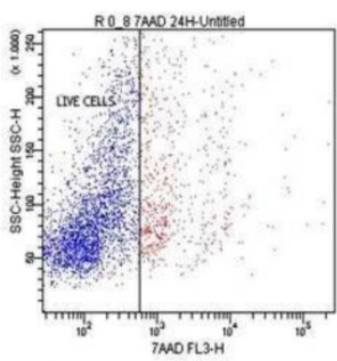

R 0,8 ANNEXIN V-PI 24H

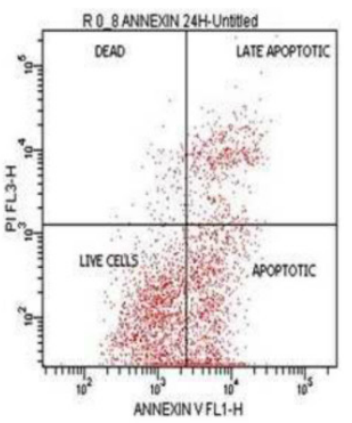

Figure 8. A) Melanoma cells $0.2 \mathrm{mg}$ ancotil and viability at 24 hours with 7-AAD, B) Retinal cells $0.2 \mathrm{mg}$ ancotil and viability at 24 hours with 7-AAD, C) Melanoma cell $0.2 \mathrm{mg}$ ancotil and viability at 24 hours with annexin, D) Retinal cells $0.2 \mathrm{mg}$ ancotil and viability at 24 hours with annexin.

A

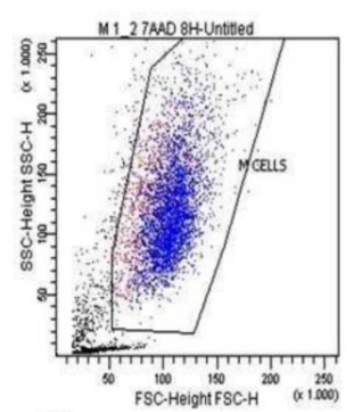

C

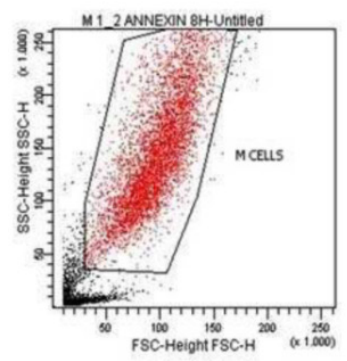

M 1,2 7AAD 8H

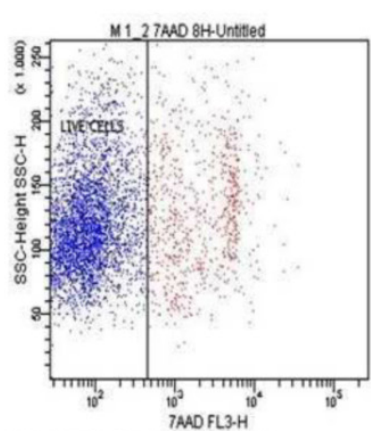

M 1,2 ANNEXIN V-PI 8H

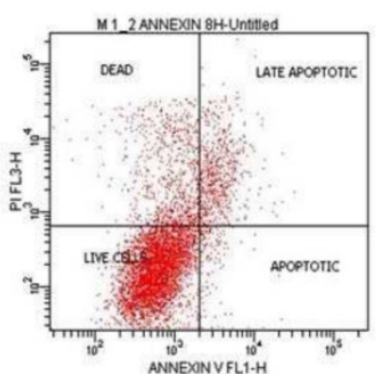

8

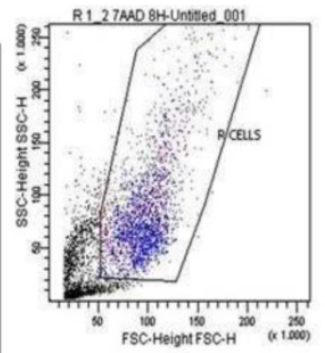

D

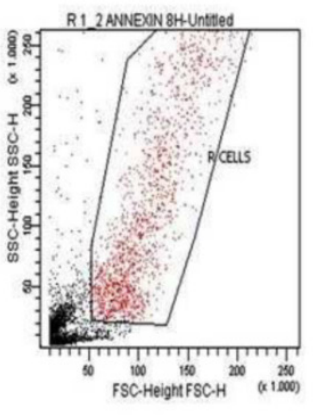

R 1,2 7AAD 8H

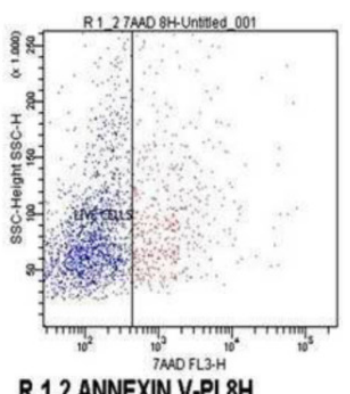

R 1,2 ANNEXIN V-PI 8H

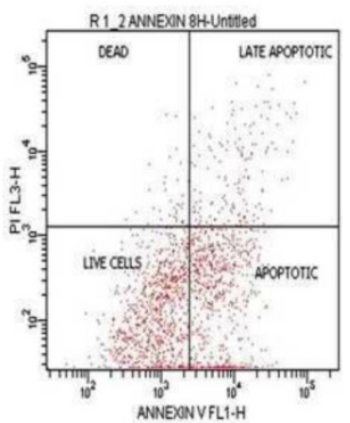

Figure 9. A) Melanoma cells $0.2 \mathrm{mg}$ ancotil and viability at 24 hours with 7-AAD, B) Retinal cells $0.2 \mathrm{mg}$ ancotil and viability at 24 hours with 7-AAD, C) Melanoma cell $0.2 \mathrm{mg}$ ancotil and viability at 24 hours with annexin, D) Retinal cells $0.2 \mathrm{mg}$ ancotil and viability at 24 hours with annexin. 
A

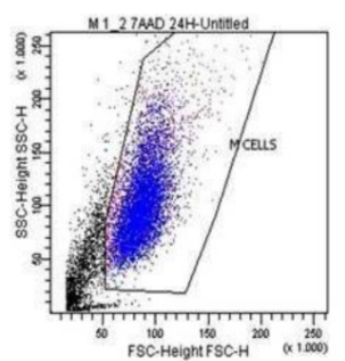

C

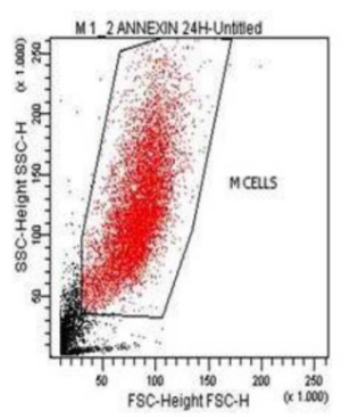

M 1,2 7AAD 24H

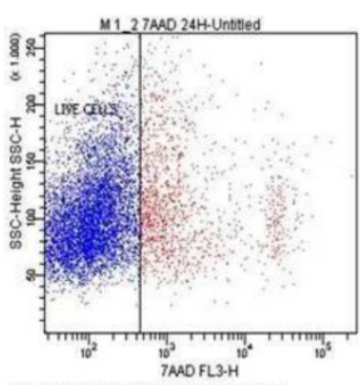

M 1,2 ANNEXIN V-PI 24H

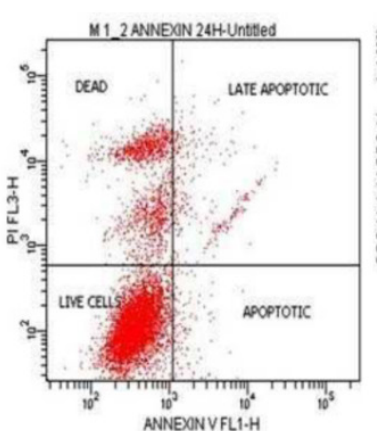

B

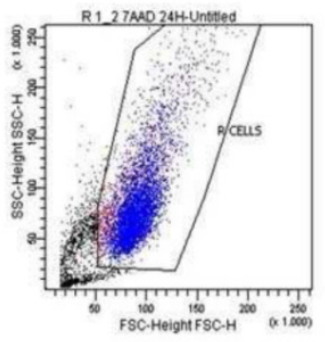

D

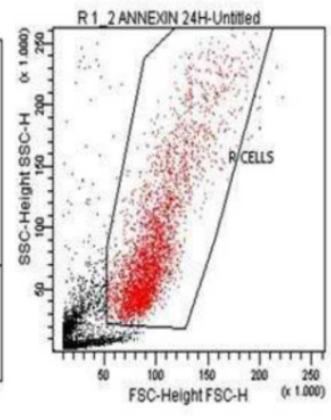

R 1,2 7AAD 24H

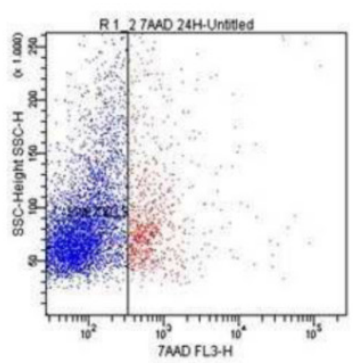

R 1,2 ANNEXIN V-PI 24H

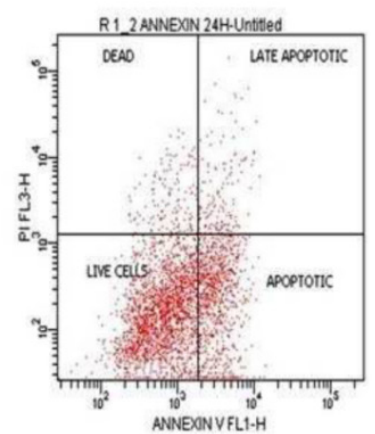

Figure 10. A) Melanoma cells $0.2 \mathrm{mg}$ ancotil and viability at 24 hours with 7-AAD, B) Retinal cells $0.2 \mathrm{mg}$ ancotil and viability at 24 hours with 7-AAD, C) Melanoma cell $0.2 \mathrm{mg}$ ancotil and viability at 24 hours with annexin, D) Retinal cells $0.2 \mathrm{mg}$ ancotil and viability at 24 hours with annexin.

\section{Acknowledgments}

The adenovirus vector was provided by Prof. A. Deisseroth, Yale University School of Medicine, and cultured in the research laboratory of the Lung Tumor Research Section of the Pulmonary Dept. Aristotle Univ. Medical School.

\section{Conflict of Interest}

None to declare.

\section{References}

1. Jerant AF, Johnson JT, Sheridan CD, Caffrey TJ. Early detection and treatment of skin cancer. Am Fam Physician. 2000;62(2):357-368, 375-356, 381-352.

2. Yang XY, Xie F, Tao R, Li AJ, Wu MC. Treatment of liver metastases from uveal melanoma: a retrospective single-center analysis. Hepatobiliary Pancreat Dis Int. 2013;12(6):602-606.

3. Chao SC, Huang SC, Hu DN, Lin HY. Subtoxic Levels of Apigenin Inhibit Expression and Secretion of VEGF by Uveal Melanoma Cells via Suppression of ERK1/2 and PI3K/Akt Pathways. Evid Based Complement Alternat Med. 2013;2013:817674.

4. Clark GS, Pappas-Politis EC, Cherpelis BS, et al. Surgical management of melanoma in situ on chronically sun-damaged skin. Cancer Control. 2008;15(3):216-224.

5. Bajetta E, Del Vecchio M, Bernard-Marty C, et al. Metastatic melanoma: chemotherapy. Semin Oncol. 2002;29(5):427-445.

6. Buzaid AC. Management of metastatic cutaneous melanoma. Oncology (Williston Park). 2004;18(11):1443-1450; discussion 1457-1449.

7. Danson S, Lorigan P. Improving outcomes in advanced malignant melanoma: update on systemic therapy. Drugs. 2005;65(6):733-743.

8. Bhatia S, Tykodi SS, Thompson JA. Treatment of metastatic melanoma: an overview. Oncology (Williston Park). 2009;23(6):488-496.

9. Curigliano G, Cardinale D, Suter T, et al. Cardiovascular toxicity induced by chemotherapy, targeted agents and radiotherapy: ESMO Clinical Practice Guidelines. Ann Oncol. 2012;23 Suppl 7:vii155-166.
10. Kuwabara $\mathrm{H}$, Fushimi $\mathrm{K}$. The impact of a new payment system with case-mix measurement on hospital practices for breast cancer patients in Japan. Health Policy. 2009;92(1):65-72.

11. Lee MK, Dodson TB, Nalliah RP, Karimbux NY, Allareddy V. Nine-year trend analysis of hospitalizations attributed to oral and oropharyngeal cancers in the United States. Oral Surg Oral Med Oral Pathol Oral Radiol. 2013.

12. Zarogoulidis $\mathrm{P}$, Chatzaki E, Porpodis K, et al. Inhaled chemotherapy in lung cancer: future concept of nanomedicine. Int J Nanomedicine. 2012;7:1551-1572.

13. Zarogoulidis P, Eleftheriadou E, Sapardanis I, et al. Feasibility and effectiveness of inhaled carboplatin in NSCLC patients. Invest New Drugs. 2012;30(4):1628-1640.

14. Zarogoulidis P, Chatzaki E, Hohenforst-Schmidt W, et al. Management of malignant pleural effusion by suicide gene therapy in advanced stage lung cancer: a case series and literature review. Cancer Gene Ther. 2012;19(9):593-600.

15. Darwiche K, Zarogoulidis P, Karamanos NK, et al. Efficacy versus safety concerns for aerosol chemotherapy in non-small-cell lung cancer: a future dilemma for micro-oncology. Future Oncol. 2013;9(4):505-525.

16. Mader RM, Kalipciyan M, Ohana P, Hochberg A, Steger GG. Suicide activation in a 5-fluorouracil resistant colon cancer model in vitro. Int J Clin Pharmacol Ther. 2011;49(1):69-70.

17. Sia KC, Huynh H, Chinnasamy N, Hui KM, Lam PY. Suicidal gene therapy in the effective control of primary human hepatocellular carcinoma as monitored by noninvasive bioimaging. Gene Ther. 2012;19(5):532-542.

18. Celikoglu F, Celikoglu SI, Goldberg EP. Bronchoscopic intratumoral chemotherapy of lung cancer. Lung Cancer. 2008;61(1):1-12.

19. Zhibing $W$, Qinghua $D$, Shenglin $M$, et al. Clinical study of cisplatin hyperthermic intraperitoneal perfusion chemotherapy in combination with docetaxel, 5-flourouracil and leucovorin intravenous chemotherapy for the treatment of advanced-stage gastric carcinoma. Hepatogastroenterology. 2013;60(128).

20. Porpodis K, Karanikas M, Zarogoulidis P, et al. A case of typical pulmonary carcinoid tumor treated with bronchoscopic therapy followed by lobectomy. $J$ Multidiscip Healthc. 2012;5:47-51.

21. Podolska K, Stachurska A, Hajdukiewicz K, Malecki M. Gene therapy prospects--intranasal delivery of therapeutic genes. Adv Clin Exp Med.2012;21(4):525-534.

22. Domvri K, Zarogoulidis P, Porpodis K, et al. Gene therapy in liver diseases: state-of-the-art and future perspectives. Curr Gene Ther. 2012;12(6):463-483.

23. Vachani A, Moon E, Wakeam E, Haas AR, Sterman DH, Albelda SM. Gene therapy for lung neoplasms. Clin Chest Med. 2011;32(4):865-885.

24. Zarogoulidis K, Zarogoulidis P, Darwiche K, et al. Malignant pleural effusion and algorithm management. J Thorac Dis. 2013;5(Suppl 4):S413-S419. 
25. Garcia-Sanchez F, Pizzorno G, Fu SQ, et al. Cytosine deaminase adenoviral vector and 5-fluorocytosine selectively reduce breast cancer cells 1 million-fold when they contaminate hematopoietic cells: a potential purging method for autologous transplantation. Blood. 1998;92(2):672-682

26. Liu Y, Ye T, Maynard J, Akbulut H, Deisseroth A. Engineering conditionally replication-competent adenoviral vectors carrying the cytosine deaminase gene increases the infectivity and therapeutic effect for breast cancer gene therapy. Cancer Gene Ther. 2006;13(4):346-356.

27. Liu Y, Deisseroth A. Oncolytic adenoviral vector carrying the cytosine deaminase gene for melanoma gene therapy. Cancer Gene Ther. 2006;13(9):845-855.

28. Akbulut H, Zhang L, Tang Y, Deisseroth A. Cytotoxic effect of replication-competent adenoviral vectors carrying L-plastin promoter regulated E1A and cytosine deaminase genes in cancers of the breast, ovary and colon. Cancer Gene Ther. 2003;10(5):388-395.

29. Freeman SM, Abboud CN, Whartenby KA, et al. The "bystander effect": tumor regression when a fraction of the tumor mass is genetically modified. Cancer Res. 1993;53(21):5274-5283.

30. Mullen CA, Kilstrup M, Blaese RM. Transfer of the bacterial gene for cytosine deaminase to mammalian cells confers lethal sensitivity to 5-fluorocytosine: a negative selection system. Proc Natl Acad Sci U S A. 1992;89(1):33-37.

31. Ram Z, Culver KW, Walbridge S, Blaese RM, Oldfield EH. In situ retroviral-mediated gene transfer for the treatment of brain tumors in rats. Cancer Res. 1993;53(1):83-88.

32. Ramesh R, Marrogi AJ, Munshi A, Abboud CN, Freeman SM. In vivo analysis of the 'bystander effect': a cytokine cascade. Exp Hematol. 1996;24(7):829-838.

33. Freeman SM, Whartenby KA, Freeman JL, Abboud CN, Marrogi AJ. In situ use of suicide genes for cancer therapy. Semin Oncol. 1996;23(1):31-45.

34. Kuriyama S, Masui K, Sakamoto T, et al. Bystander effect caused by cytosine deaminase gene and 5-fluorocytosine in vitro is substantially mediated by generated 5-fluorouracil. Anticancer Res. 1998;18(5A):3399-3406.

35. Zhong Z, Wan Y, Shi S, Han J, Zhang Z, Sun X. Co-delivery of adenovirus and carmustine by anionic liposomes with synergistic anti-tumor effects. Pharm Res. 2012;29(1):145-157.

36. Saito A, Morishita N, Mitsuoka C, et al. Intravenous injection of irradiated tumor cell vaccine carrying oncolytic adenovirus suppressed the growth of multiple lung tumors in a mouse squamous cell carcinoma model. J Gene Med. 2011;13(6):353-361.

37. Zhu Y, Lv H, Xie Y, Sheng W, Xiang J, Yang J. Enhanced tumor suppression by an ING4/IL-24 bicistronic adenovirus-mediated gene cotransfer in human non-small cell lung cancer cells. Cancer Gene Ther. 2011;18(9):627-636.

38. Zhu Y, Farina JB, Meshack S, et al. Anti-tumor effects of adenovirus containing human growth hormone sequences in a mouse model of human ovarian cancer. Endocrine. 2010;37(3):430-439.

39. Ahn YH, Yi H, Shin JY, et al. STAT3 silencing enhances the efficacy of the HSV.tk suicide gene in gastrointestinal cancer therapy. Clin Exp Metastasis. 2012;29(4):359-369.

40. Finzi L, Kraemer A, Capron C, et al. Improved retroviral suicide gene transfer in colon cancer cell lines after cell synchronization with methotrexate. J Exp Clin Cancer Res. 2011;30:92.

41. Cramer F, Christensen CL, Poulsen TT, Badding MA, Dean DA, Poulsen HS. Insertion of a nuclear factor kappa B DNA nuclear-targeting sequence potentiates suicide gene therapy efficacy in lung cancer cell lines. Cancer Gene Ther. 2012;19(10):675-683.

42. Qiu Y, Peng GL, Liu QC, Li FL, Zou XS, He JX. Selective killing of lung cancer cells using carcinoembryonic antigen promoter and double suicide genes, thymidine kinase and cytosine deaminase (pCEA-TK/CD). Cancer Lett. 2012;316(1):31-38

43. Niu HX, Du T, Xu ZF, Zhang XK, Wang RG. Role of wild type p53 and double suicide genes in interventional therapy of liver cancer in rabbits. Acta Cir Bras. 2012;27(8):522-528

44. Marukawa $Y$, Nakamoto $Y$, Kakinoki $K$, et al. Membrane-bound form of monocyte chemoattractant protein-1 enhances antitumor effects of suicide gene therapy in a model of hepatocellular carcinoma. Cancer Gene Ther. 2012;19(5):312-319.

45. Li S, Gao Y, Pu K, Ma L, Song X, Liu Y. All-trans retinoic acid enhances bystander effect of suicide-gene therapy against medulloblastomas. Neurosci Lett. 2011;503(2):115-119.

46. Won YW, Kim KM, An SS, Lee M, Ha Y, Kim YH. Suicide gene therapy using reducible poly (oligo-D-arginine) for the treatment of spinal cord tumors. Biomaterials. 2011;32(36):9766-9775.

47. Akerstrom V, Chen C, Lan MS, Breslin MB. Adenoviral insulinoma-associated protein 1 promoter-driven suicide gene therapy with enhanced selectivity for treatment of neuroendocrine cancers. Ochsner J. 2013;13(1):91-99.

48. Lu M, Freytag SO, Stricker H, Kim JH, Barton K, Movsas B. Adaptive seamless design for an efficacy trial of replication-competent adenovirus-mediated suicide gene therapy and radiation in newly-diagnosed prostate cancer (ReCAP Trial). Contemp Clin Trials.2011;32(3):453-460.

49. Ma S, Zhao L, Zhu Z, et al. The multisubstrate deoxyribonucleoside kinase of Drosophila melanogaster as a therapeutic suicide gene of breast cancer cells. $J$ Gene Med. 2011;13(6):305-311.

50. Yi BR, Choi KJ, Kim SU, Choi KC. Therapeutic potential of stem cells expressing suicide genes that selectively target human breast cancer cells: evidence that they exert tumoricidal effects via tumor tropism (review). Int $J$ Oncol. 2012;41(3):798-804
51. Yin X, Yu B, Tang Z, et al. Bifidobacterium infantis-mediated HSV-TK/GCV suicide gene therapy induces both extrinsic and intrinsic apoptosis in a rat model of bladder cancer. Cancer Gene Ther. 2013;20(2):77-81.

52. Schmidt M, Gruensfelder P, Roller J, Hagen R. Suicide gene therapy in head and neck carcinoma cells: an in vitro study. Int J Mol Med. 2011;27(4):591-597.

53. Wang C, Natsume A, Lee HJ, et al. Neural stem cell-based dual suicide gene delivery for metastatic brain tumors. Cancer Gene Ther. 2012;19(11):796-801.

54. Zhao Y, Lam DH, Yang J, et al. Targeted suicide gene therapy for glioma using human embryonic stem cell-derived neural stem cells genetically modified by baculoviral vectors. Gene Ther. 2012;19(2):189-200.

55. Kosaka H, Ichikawa T, Kurozumi $\mathrm{K}$, et al. Therapeutic effect of suicide gene-transferred mesenchymal stem cells in a rat model of glioma. Cancer Gene Ther. 2012;19(8):572-578.

56. Cottin S, Gould PV, Cantin L, Caruso M. Gap junctions in human glioblastomas: implications for suicide gene therapy. Cancer Gene Ther. 2011;18(9):674-681.

57. Finocchiaro LM, Villaverde MS, Gil-Cardeza ML, Riveros MD, Glikin GC. Cytokine-enhanced vaccine and interferon-beta plus suicide gene as combined therapy for spontaneous canine sarcomas. Res Vet Sci. 2011;91(2):230-234.

58. Du BY, Guo YR, Yi H, Tan YH, Wu YY. [The preliminary research on the gap junction mechanisms for synergistic effects of liuwei di-huang pill containing serum on suicide gene therapy of melanoma]. Zhongguo Zhong Xi Yi Jie $\mathrm{He} \mathrm{Za}$ Zhi. 2013;33(5):651-658.

59. Leng A, Yang J, Liu T, et al. Nanoparticle-delivered VEGF-silencing cassette and suicide gene expression cassettes inhibit colon carcinoma growth in vitro and in vivo. Tumour Biol. 2011;32(6):1103-1111.

60. Liu T, Ye L, He Y, et al. Combination gene therapy using VEGF-shRNA and fusion suicide gene yCDglyTK inhibits gastric carcinoma growth. Exp Mol Pathol. 2011;91(3):745-752.

61. Xu Y, Hou J, Liu Z, et al. Gene therapy with tumor-specific promoter mediated suicide gene plus IL-12 gene enhanced tumor inhibition and prolonged host survival in a murine model of Lewis lung carcinoma. J Transl Med. 2011;9:39.

62. Bondanza A, Hambach L, Aghai Z, et al. IL-7 receptor expression identifies suicide gene-modified allospecific CD8 $+\mathrm{T}$ cells capable of self-renewal and differentiation into antileukemia effectors. Blood. 2011;117(24):6469-6478.

63. Michaelsen SR, Christensen CL, Sehested M, et al. Single agent- and combination treatment with two targeted suicide gene therapy systems is effective in chemoresistant small cell lung cancer cells. I Gene Med. 2012;14(7):445-458.

64. Sun X, Xing L, Deng X, et al. Hypoxia targeted bifunctional suicide gene expression enhances radiotherapy in vitro and in vivo. Radiother Oncol. 2012;105(1):57-63.

65. Kakinoki K, Nakamoto Y, Kagaya $\mathrm{T}$, et al. Prevention of intrahepatic metastasis of liver cancer by suicide gene therapy and chemokine ligand 2/monocyte chemoattractant protein-1 delivery in mice. I Gene Med. 2010;12(12):1002-1013.

66. Neschadim A, Wang JC, Lavie A, Medin JA. Bystander killing of malignant cells via the delivery of engineered thymidine-active deoxycytidine kinase for suicide gene therapy of cancer. Cancer Gene Ther. 2012;19(5):320-327.

67. Amano S, Gu C, Koizumi S, Tokuyama T, Namba H. Tumoricidal bystander effect in the suicide gene therapy using mesenchymal stem cells does not injure normal brain tissues. Cancer Lett. 2011;306(1):99-105.

68. Niess H, Bao Q, Conrad C, et al. Selective targeting of genetically engineered mesenchymal stem cells to tumor stroma microenvironments using tissue-specific suicide gene expression suppresses growth of hepatocellular carcinoma. Ann Surg. 2011;254(5):767-774; discussion 774-765.

69. Yang ZF, Zhan YQ, Chen RC, et al. A prospective comparison of the epidemiological and clinical characteristics of pandemic (H1N1) 2009 influenza A virus and seasonal influenza A viruses in Guangzhou, South China in 2009. Jpn J Infect Dis. 2012;65(3):208-214.

70. Luo XR, Li JS, Niu Y, Miao L. Adenovirus-mediated double suicide gene selectively kills gastric cancer cells. Asian Pac J Cancer Prev. 2012;13(3):781-784.

71. Duan $X$, Wang $P$, Men $K$, et al. Treating colon cancer with a suicide gene delivered by self-assembled cationic MPEG-PCL micelles. Nanoscale. 2012;4(7):2400-2407.

72. Sterman DH, Recio A, Carroll RG, et al. A phase I clinical trial of single-dose intrapleural IFN-beta gene transfer for malignant pleural mesothelioma and metastatic pleural effusions: high rate of antitumor immune responses. Clin Cancer Res. 2007:13(15 Pt 1):4456-4466.

73. Sterman DH, Recio A, Haas AR, et al. A phase I trial of repeated intrapleural adenoviral-mediated interferon-beta gene transfer for mesothelioma and metastatic pleural effusions. Mol Ther. 2010;18(4):852-860.

74. Dong M, Li X, Hong LJ, et al. Advanced malignant pleural or peritoneal effusion in patients treated with recombinant adenovirus p53 injection plus cisplatin. J Int Med Res. 2008;36(6):1273-1278.

75. Zhao WZ, Wang JK, Li W, Zhang XL. [Clinical research on recombinant human Ad-p53 injection combined with cisplatin in treatment of malignant pleural effusion induced by lung cancer]. Ai Zheng. 2009;28(12):1324-1327.

76. Rainov NG. A phase III clinical evaluation of herpes simplex virus type 1 thymidine kinase and ganciclovir gene therapy as an adjuvant to surgical resection and radiation in adults with previously untreated glioblastoma multiforme. Hum Gene Ther. 2000;11(17):2389-2401.

77. Voges J, Reszka R, Gossmann A, et al. Imaging-guided convection-enhanced delivery and gene therapy of glioblastoma. Ann Neurol. 2003;54(4):479-487. 
78. Nasu Y, Saika T, Ebara S, et al. Suicide gene therapy with adenoviral delivery of HSV-tK gene for patients with local recurrence of prostate cancer after hormonal therapy. Mol Ther. 2007;15(4):834-840.

79. Xu F, Li S, Li XL, et al. Phase I and biodistribution study of recombinant adenovirus vector-mediated herpes simplex virus thymidine kinase gene and ganciclovir administration in patients with head and neck cancer and other malignant tumors. Cancer Gene Ther.2009;16(9):723-730.

80. Li N, Zhou J, Weng D, et al. Adjuvant adenovirus-mediated delivery of herpes simplex virus thymidine kinase administration improves outcome of liver transplantation in patients with advanced hepatocellular carcinoma. Clin Cancer Res. 2007;13(19):5847-5854.

81. Freytag SO, Movsas B, Aref I, et al. Phase I trial of replication-competent adenovirus-mediated suicide gene therapy combined with IMRT for prostate cancer. Mol Ther. 2007;15(5):1016-1023.

82. Pandha HS, Martin LA, Rigg A, et al. Genetic prodrug activation therapy for breast cancer: A phase I clinical trial of erbB-2-directed suicide gene expression. J Clin Oncol. 1999;17(7):2180-2189.

83. Freytag SO, Stricker H, Pegg J, et al. Phase I study of replication-competent adenovirus-mediated double-suicide gene therapy in combination with conventional-dose three-dimensional conformal radiation therapy for the treatment of newly diagnosed, intermediate- to high-risk prostate cancer. Cancer Res. 2003;63(21):7497-7506.

84. Nemunaitis J, Cunningham C, Senzer N, et al. Pilot trial of genetically modified, attenuated Salmonella expressing the E. coli cytosine deaminase gene in refractory cancer patients. Cancer Gene Ther. 2003;10(10):737-744.

85. Zarogoulidis P, Darwiche K, Sakkas A, et al. Suicide Gene Therapy for Cancer - Current Strategies. I Genet Syndr Gene Ther. 2013;4.

86. Preuss E, Muik A, Weber K, Otte J, von Laer D, Fehse B. Cancer suicide gene therapy with TK.007: superior killing efficiency and bystander effect. J Mol Med (Berl). 2011;89(11):1113-1124.

87. Gruber C Gratz IK Murauer EM, et al Spliceosome-mediated RNA trans-splicing facilitates targeted delivery of suicide genes to cancer cells. Mol Cancer Ther. 2011;10(2):233-241.

88. Di Stasi A, Tey SK, Dotti G, et al. Inducible apoptosis as a safety switch for adoptive cell therapy. N Engl J Med. 2011;365(18):1673-1683.

89. Malecki M, Anderson M, Beauchaine M, Seo S, Tambokan X. TRA-1-60(+), SSEA-4(+), Oct4A $(+), \operatorname{Nanog}(+)$ Clones of Pluripotent Stem Cells in the Embryonal Carcinomas of the Ovaries. I Stem Cell Res Ther. 2012;2(5).

90. Park HS, Cheon J, Cho HY, et al. In vivo characterization of a prostate-specific antigen promoter-based suicide gene therapy for the treatment of benign prostatic hyperplasia. Gene Ther. 2003;10(13):1129-1134.

91. Malecki M. Cancer suicide gene therapy: Apoptosis of the ovarian cancer cells induced by EGFRvIII targeted delivery and cell nucleus targeted expression of the DNase transgenes. Journal of Genetic Syndromes \& Gene Therapy. 2012; in press.

92. Yamamoto M, Alemany R, Adachi Y, Grizzle WE, Curiel DT. Characterization of the cyclooxygenase-2 promoter in an adenoviral vector and its application for the mitigation of toxicity in suicide gene therapy of gastrointestinal cancers. Mol Ther. 2001;3(3):385-394.

93. Song JS, Kim HP, Yoon WS, et al. Adenovirus-mediated suicide gene therapy using the human telomerase catalytic subunit (hTERT) gene promoter induced apoptosis of ovarian cancer cell line. Biosci Biotechnol Biochem. 2003;67(11):2344-2350.

94. Ishiwata N, Inase N, Fujie T, Tamaoka M, Yoshizawa Y. Suicide gene therapy using keratin 19 enhancer and promoter in malignant mesothelioma cells. Anticancer Res. 2003;23(2B):1405-1409.

95. Peng XY, Won JH, Rutherford T, et al. The use of the L-plastin promoter for adenoviral-mediated, tumor-specific gene expression in ovarian and bladder cancer cell lines. Cancer Res. 2001;61(11):4405-4413.

96. Graham FL, Prevec L. Manipulation of adenovirus vectors. Methods Mol Biol. 1991;7:109-128.

97. Carey TE, Takahashi T, Resnick LA, Oettgen HF, Old LJ. Cell surface antigens of human malignant melanoma: mixed hemadsorption assays for humoral immunity to cultured autologous melanoma cells. Proc Natl Acad Sci U S A. 1976;73(9):3278-3282.

98. Dunn KC, Aotaki-Keen AE, Putkey FR, Hjelmeland LM. ARPE-19, a human retinal pigment epithelial cell line with differentiated properties. Exp Eye Res. 1996;62(2):155-169.

99. Wiegand C, Hipler UC. Methods for the measurement of cell and tissue compatibility including tissue regeneration processes. GMS Krankenhhyg Interdiszip. 2008;3(1):Doc12.

100. Van Hooijdonk CA, Glade CP, Van Erp PE. TO-PRO-3 iodide: a novel HeNe laser-excitable DNA stain as an alternative for propidium iodide in multiparameter flow cytometry. Cytometry. 1994;17(2):185-189. 